\title{
Molecular Approaches for Insect Pest Management in Rice
}

\author{
Jagadish S. Bentur, R. M. Sundaram, Satendra Kumar Mangrauthia, \\ and Suresh Nair
}

\begin{abstract}
This chapter focuses on the progress made in using molecular tools in understanding resistance in rice to insect pests and breeding rice for multiple and durable insect resistance. Currently, molecular markers are being extensively used to tag, map, introgress, and clone plant resistance genes against gall midge, planthoppers, and leafhoppers. Studies on cloned insect resistance genes are leading to a better understanding of plant defense against insect pests under different feeding guilds. While marker-assisted breeding is successfully tackling problems in durable and multiple pest resistance in rice, genomics of plants and insects has identified RNAi-based gene silencing as an alternative approach for conferring insect resistance. The use of these techniques in rice is in the developmental stage, with the main focus on brown planthopper and yellow stem borer. CRISPR-based genome editing techniques for pest control in plants has just begun. Insect susceptibility genes (negative regulators of resistance genes) in plants are apt targets for this approach while gene drive in insect populations, as a tool to study rice-pest interactions, is another concept being tested. Transformation of crop plants with diverse insecticidal genes is a proven technology with potential for commercial success. Despite advances in the development and testing of transgenic rice for insect resistance, no insect-resistant rice cultivar is now being commercially cultivated. An array of molecular tools is being used to study insect-rice interactions at transcriptome, proteome, metabolome, mitogenome, and metagenome levels, especially with reference to $\mathrm{BPH}$ and gall midge, and such studies are uncovering new approaches for insect pest management and for understanding population genetics and phylogeography of rice pests. Thus, it is evident that the new knowledge being gained through these studies has provided us with new tools and information for
\end{abstract}

\author{
J. S. Bentur $(\bowtie)$ \\ Agri Biotech Foundation, Hyderabad, Telangana, India \\ R. M. Sundaram \\ ICAR-Indian Institute of Rice Research, Hyderabad, Telangana, India \\ S. K. Mangrauthia \\ ICAR-Indian Institute of Rice Research, Hyderabad, Telangana, India \\ S. Nair \\ Plant-Insect Interaction Group, International Centre for Genetic Engineering and \\ Biotechnology, New Delhi, India
}


facing future challenges. However, what is also evident is that our attempts to manage rice pests cannot be a one-time effort but must be a continuing one.

Keywords Insect resistance · Molecular markers · Marker-assisted breeding · RNAi $\cdot$ Genome editing $\cdot$ Transgenic rice $\cdot$ Insect-plant interaction

\section{Introduction}

Insect pests of rice form a formidable biotic stress component and a significant production constraint across the globe. Although more than 200 insect species are reported to feed on rice plants, about a dozen of them are economically important in a specific rice ecosystem at a given time. Several of these have coevolved over thousands of years along with their host and many have no alternate host. The pest complex of rice is represented by insects from all the feeding guilds, from defoliators, tissue borers, and sap-suckers to gall formers, and several of these are occupied by a complex of species (Heinrichs 1994). Most important among these are stem borers: yellow stem borer (YSB), Scirpophaga incertulas; striped stem borer (SSB), Chilo suppressalis; and pink stem borer (PSB), Sesamia inferens; planthoppers: brown planthopper (BPH), Nilaparvata lugens; white-backed planthopper (WBPH), Sogatella furcifera; and small brown planthopper (SBPH), Laodelphax striatellus; leafhoppers: green leafhopper (GLH), Nephottetix virescens; green rice leafhopper (GRL/GRH), Nephotettix cincticeps; and zigzag leafhopper (ZLH), Recilia dorsalis; gall midges: Asian rice gall midge (ARGM), Orseolia oryzae; and African rice gall midge (AfRGM), Orseolia oryzivora; and leaffolders: Cnaphalocrocis medinalis and Marasmia spp. Several other insects such as rice hispa, grain bugs, aphids, mealy bug, and stem fly are of minor or regional importance (Bentur 2010).

Several studies reported yield losses due to either a single pest or a complex of pests but most of them end up with either overestimating or underestimating the damage caused by these pests. Savary et al. (2000) critically studied yield losses caused by different pests under varying production environments and suggested that stem borer damage at heading stage accounted for $2.3 \%$ loss. They also noted that yield attrition from chronic injuries by stem borer deadheart damage and defoliation is underestimated. Although this study represented the macro-level scenario, microlevel yield losses due to any single or combination of insect pests can be high and deserves to be mitigated. Deutsch et al. (2018) predict future increases in yield loss in rice because of insect pests under the scenario of global warming.

Past experience has clearly shown that any unilateral approach based on chemical control, plant resistance, biocontrol, or behavioral means with pheromones has not provided desirable and sustainable solutions to pest problems. However, an early lead in exploring host-plant resistance taken by the International Rice Research Institute and emulated by various national programs paved the way for breeding for insect resistance with exemplary success against pests such as striped stem borer, 
gall midge, and planthoppers. But the first wave of success was countered by the rapid evolution of virulent biotypes. With the recent advances in molecular biology and biotechnology, researchers now have a new set of tools with which they can address several problems at the molecular level and identify new strategies to overcome old problems. In this chapter, we examine progress made through the classical approach and how the limitations of classical approach-based insect resistance and breeding for multiple and durable insect resistance in rice are being overcome with molecular marker-based approaches. In addition, we attempt to present the future scenario of genomics-based tools that may provide novel strategies of pest management.

\section{Classical Approach Through Host-Plant Resistance Gene Deployment}

Following the seminal publication of R.H. Painter (1951), genetic resistance in the host plant has been extensively explored and plant resistance $(\mathrm{R})$ genes have been transferred to elite cultivars of field crops and other economically important plant species. Classical breeding methods and phenotypic selections were followed to achieve this until molecular markers were discovered. Currently, desired R-genes can be transferred and pyramided through marker-assisted selection and breeding. The status of donor sources, genetics of resistance, tagging and mapping of R-genes, and reported gene-linked markers are provided in what follows for the major insect pests of rice.

\subsection{Gall Midge}

Asian rice gall midge (ARGM) is a serious pest of rice in South and Southeast Asia. In India, gall midge damage is estimated to cause an annual yield loss of about USD 80 million (Bentur et al. 2003). The insect displays a unique life cycle, which is completed in 3-4 weeks. Maggots hatched from eggs laid on the plant surface crawl down between leaf sheaths to reach the apical meristem to feed. The insect feeds by laceration of the apical meristem and secretion of saliva, resulting in hypertrophy and hyperplasia of cells, ultimately leading to the development of a nutritive tissue and a gall chamber in the tiller. The insect also renders the tiller sterile and arrests further differentiation. Maggots cease feeding in the third instar and pupate in the gall. The adult fly emerges from this modified sheath gall called "silver shoot," which is a typical symptom of gall midge damage. ARGM is predominantly a vegetative-stage pest and, in the event of a high percentage of tillers being converted into galls, there will be a proportionate decrease in the number of productive tillers, panicles, and therefore grain yield. 
Rice varieties differ in their response to gall midge infestation. A small proportion of varieties is immune to pest attack by effectively killing the maggot within hours of feeding. The resistance mechanism displayed by the varieties is categorized into two distinct types. A majority of the resistant rice genotypes express a hypersensitive reaction (HR), leading to tissue necrosis at the site of maggot feeding, and are referred to as $\mathrm{HR}+\mathrm{ve}(\mathrm{HR}+)$ types, whereas a few of the resistant genotypes do not display HR but still maggot mortality is noticed, and these are termed HR -ve (HR-) types. The role of phenols in HR+ resistance has been reported (Amudhan et al. 1999). Because the nature of resistance is antibiosis in both HR+ and $\mathrm{HR}$ - types, host-plant resistance is the most effective way of managing the pest (Bentur et al. 2003).

Field and greenhouse evaluations of more than 50,000 germplasm accessions resulted in the identification of more than 300 primary sources of resistance (Bentur et al. 2011). Studies on the genetics of gall midge resistance in rice have often shown the involvement of a single dominant or recessive gene. To date, 12 genes conferring resistance against the pest have been reported (Himabindu et al. 2010; Leelagud et al. 2020), 10 of which are dominant ( $G m 1$ through $G m 11$, except gm3 and gm12). The presence of gall midge biotypes within India was suspected during the early phase of breeding for resistance. So far, seven distinct biotypes have been characterized based on their reaction pattern against five groups of differential rice varieties (Vijayalakshmi et al. 2006). Similar to the interaction between pathogens and their plant hosts, a gene-for-gene interaction has been reported between rice resistance genes (i.e., $\mathrm{R}$ genes) and gall midge biotypes (Nair et al. 2011). Each of the biotypes displays a specific range of virulence against R-genes, and likewise each R-gene confers resistance to specific biotypes, which also implies that none of the R-genes conferred resistance to all biotypes and none of the biotypes showed virulence against all of the R-genes. Hence, it is possible to extend the range of resistance against biotypes by combining diverse resistance genes through gene pyramiding.

Of the 12 gall midge resistance genes identified thus far, 10 ( Gml, Gm2, gm3, $\mathrm{Gm} 4, \mathrm{Gm} 5, \mathrm{Gm} 6, \mathrm{Gm} 7, \mathrm{Gm} 8, \mathrm{Gm} 11$, and $\mathrm{gm} 12$ ) have been tagged and mapped with reported linked markers (Table 1). As it is well known that single gene-conferred resistance against gall midge can break down within a short time, the strategy of pyramiding two or more genes with divergent mechanisms of resistance (i.e., HR+ and $\mathrm{HR}-$ ) has been advocated for durable resistance against the insect pest (Sundaram et al. 2013). So far, three gall midge resistance genes, gm3 (Sama et al. 2014), Gm4 (Divya et al. 2015), and Gm8 (Divya et al. 2018b), have been cloned and characterized, and another gene, Gm2, has been reported to be allelic to gm3 (Sama et al. 2014; Sundaram 2007). The recessive resistance gene, gm3, which displays $\mathrm{HR}+$, encodes an NB-ARC (NBS-LRR) domain-containing protein, while the dominant gene, $G m 4$, which also displays $\mathrm{HR}+$, encodes a leucine-rich repeat (LRR) protein, and $G m 8$, displaying $\mathrm{HR}-$, encodes a proline-rich protein (PRP). It is desirable to deploy two or more previously undeployed genes that differ in their mechanism of resistance, for example, Gm4 (HR+) and Gm8 (HR-) genes would meet the above-specified requirements. Another gene, gm3, may also be considered 


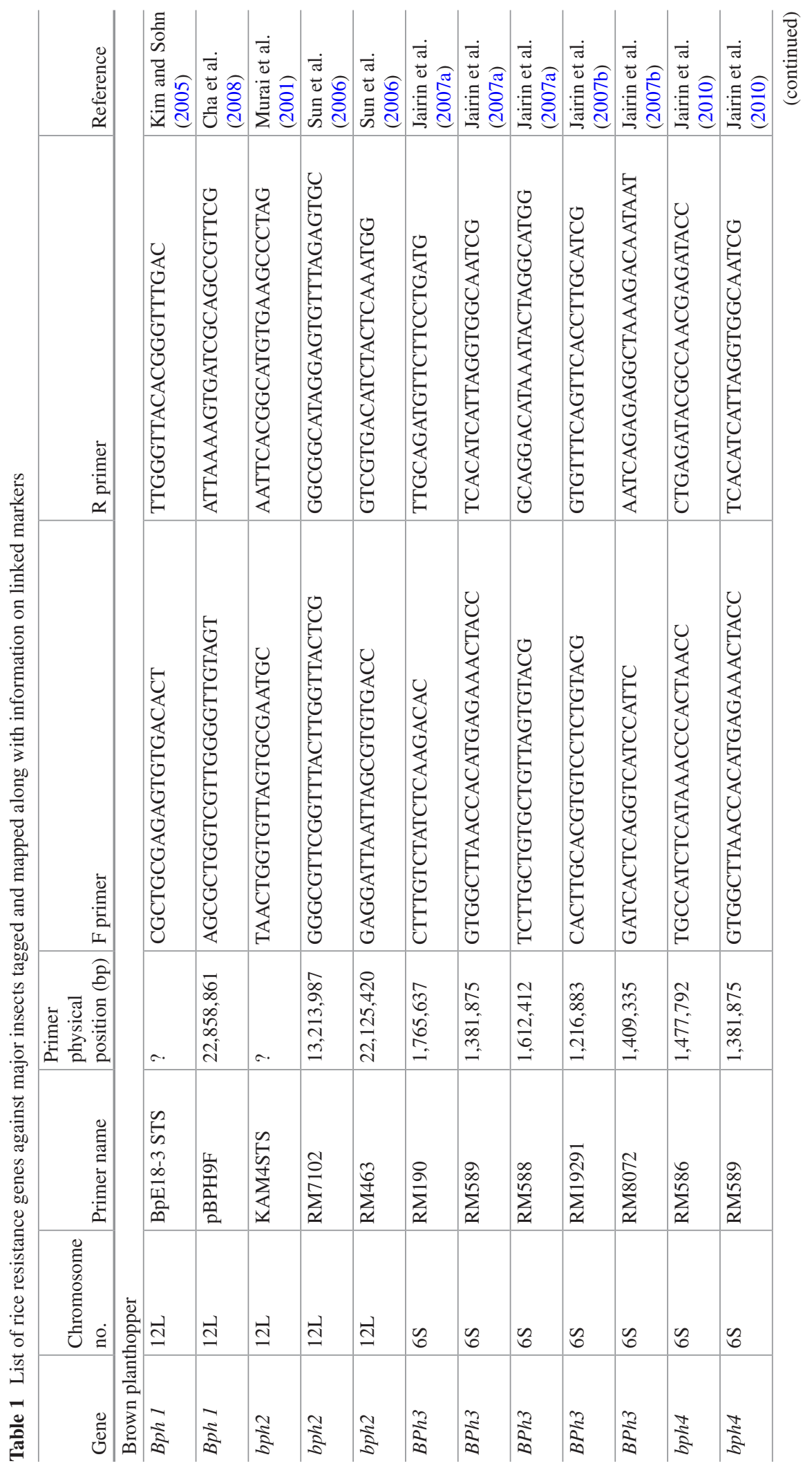




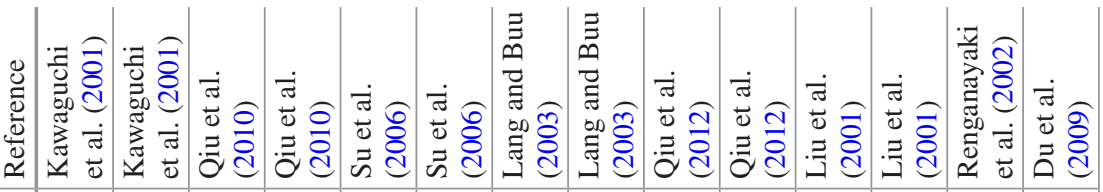
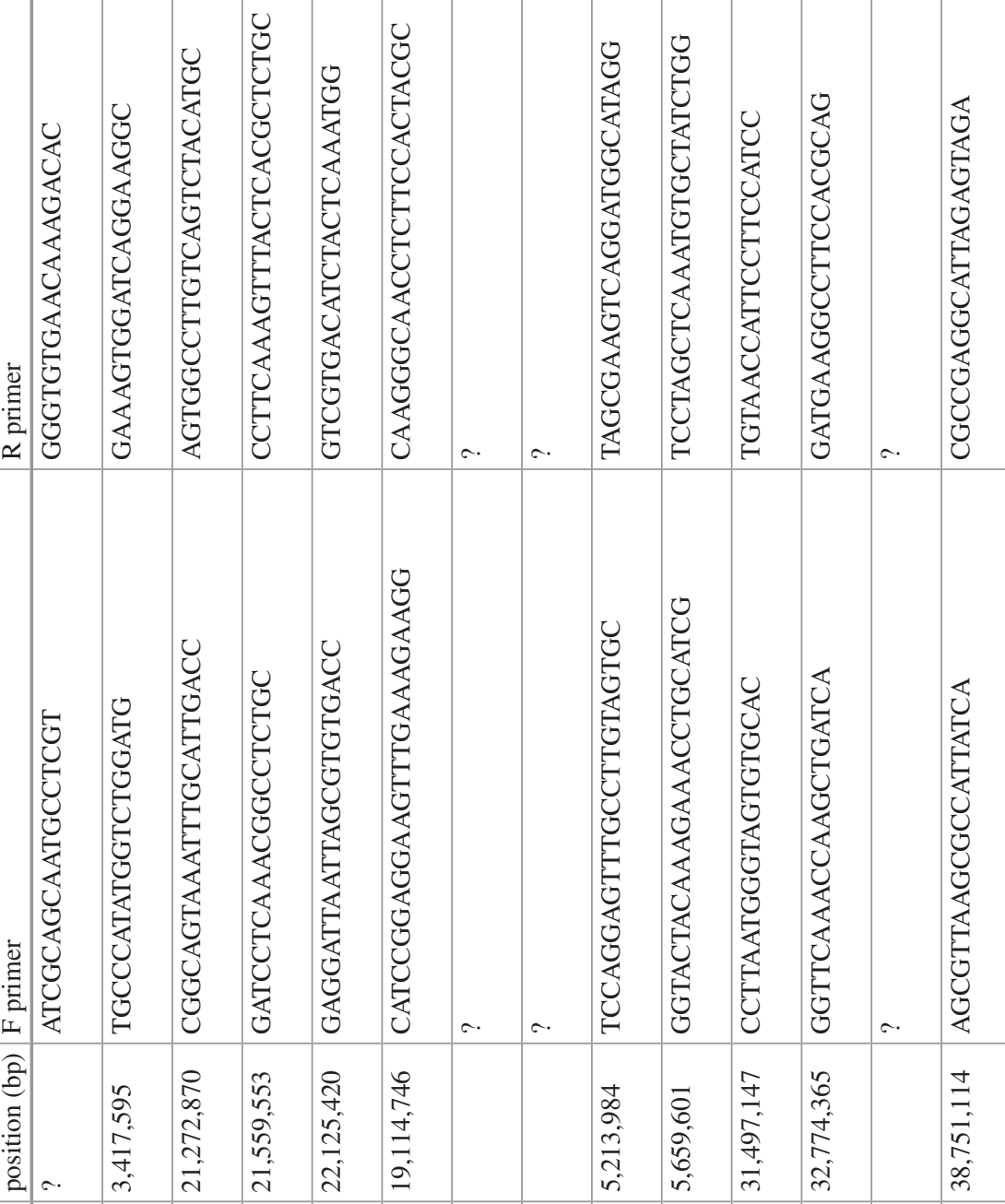

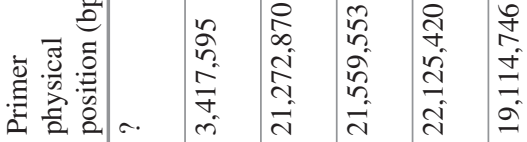

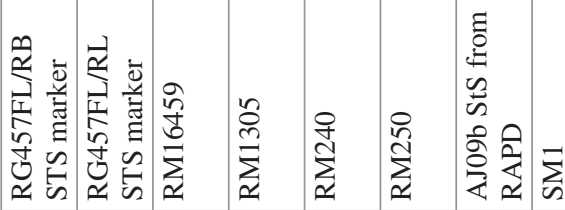

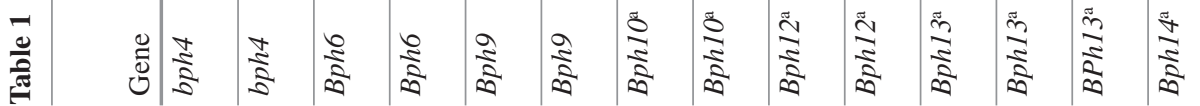




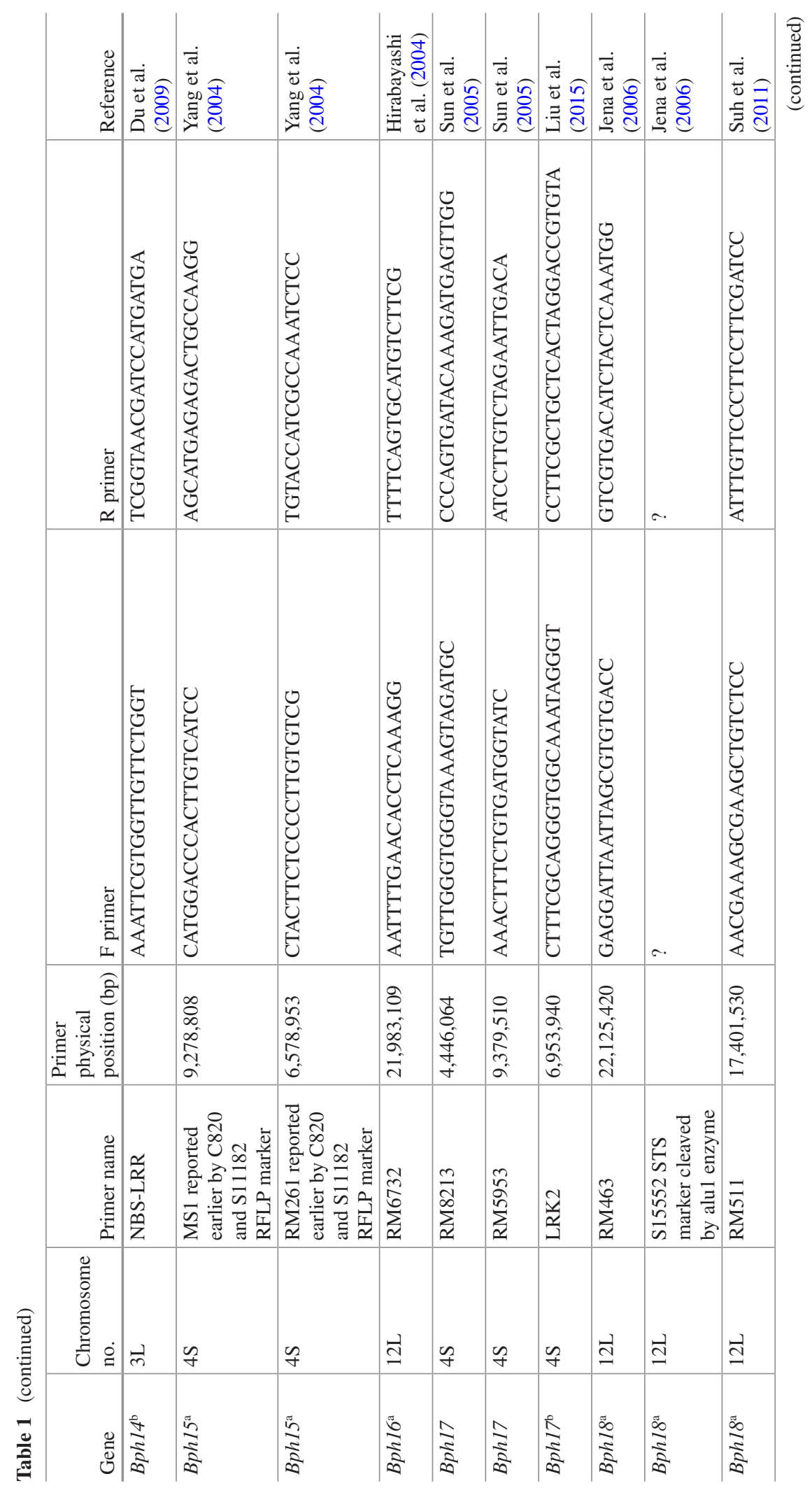




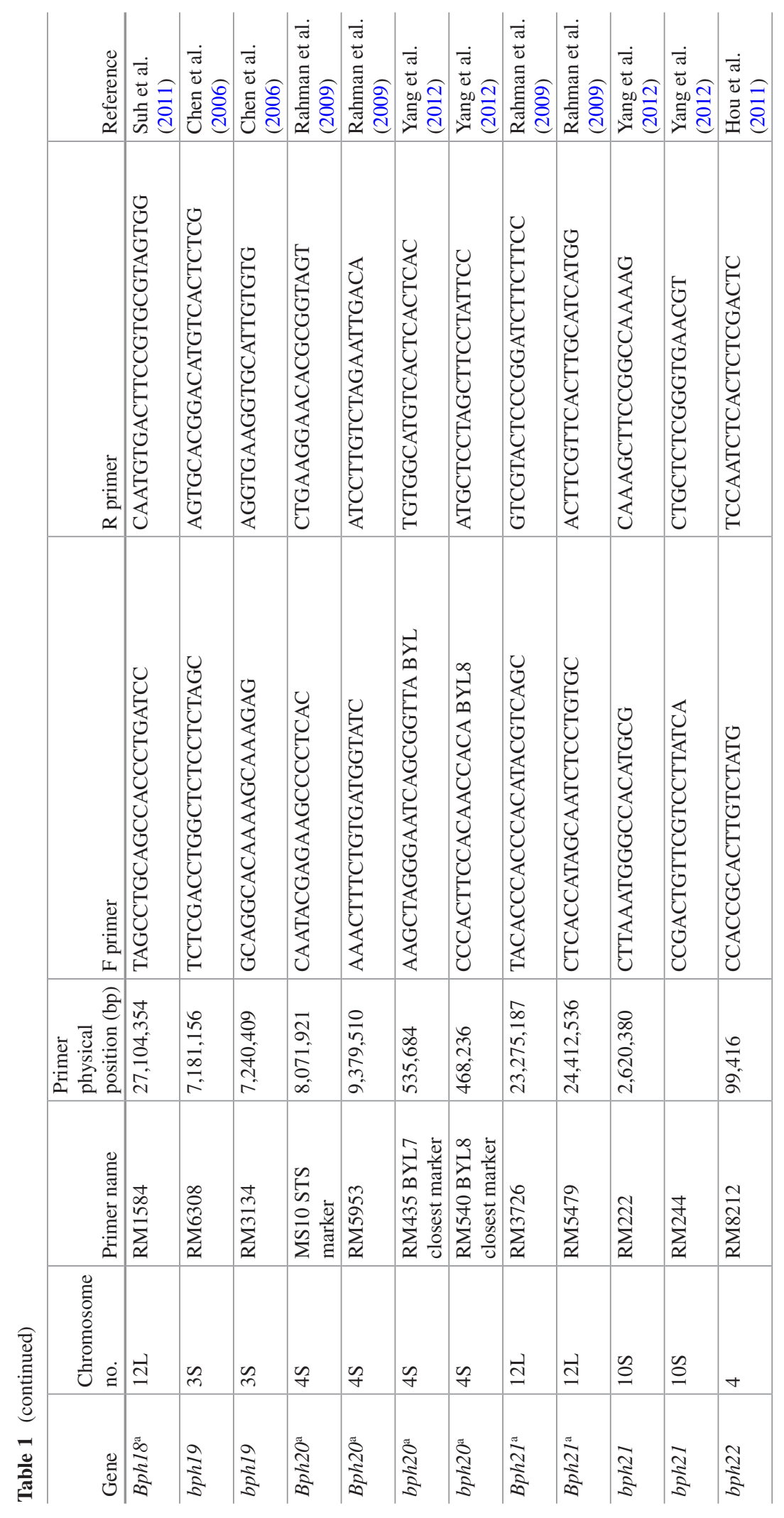




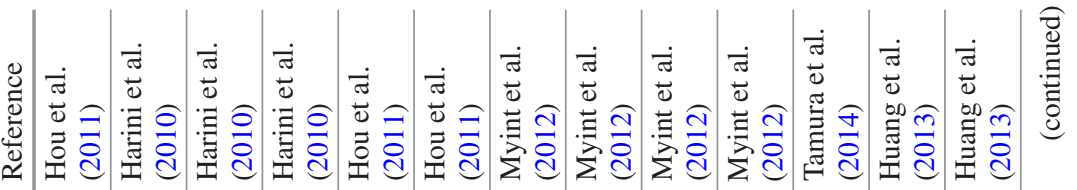

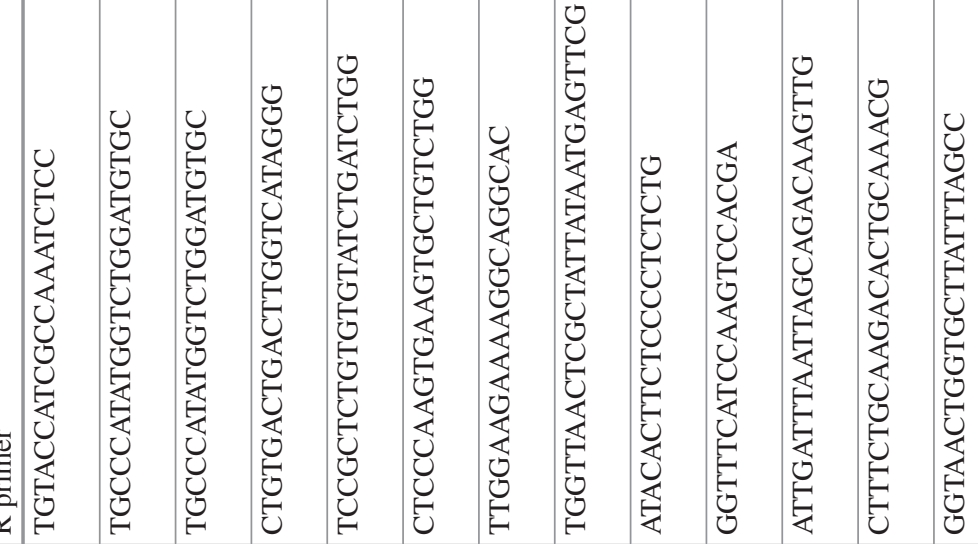

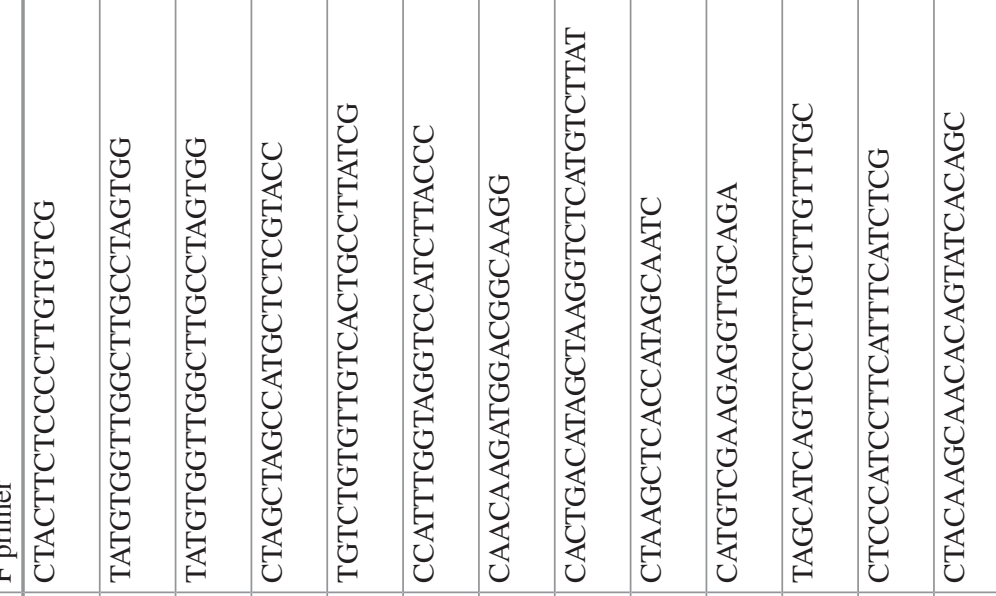

के

旁

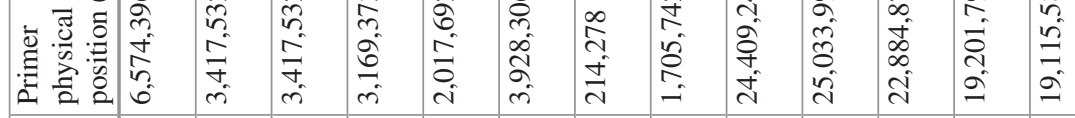

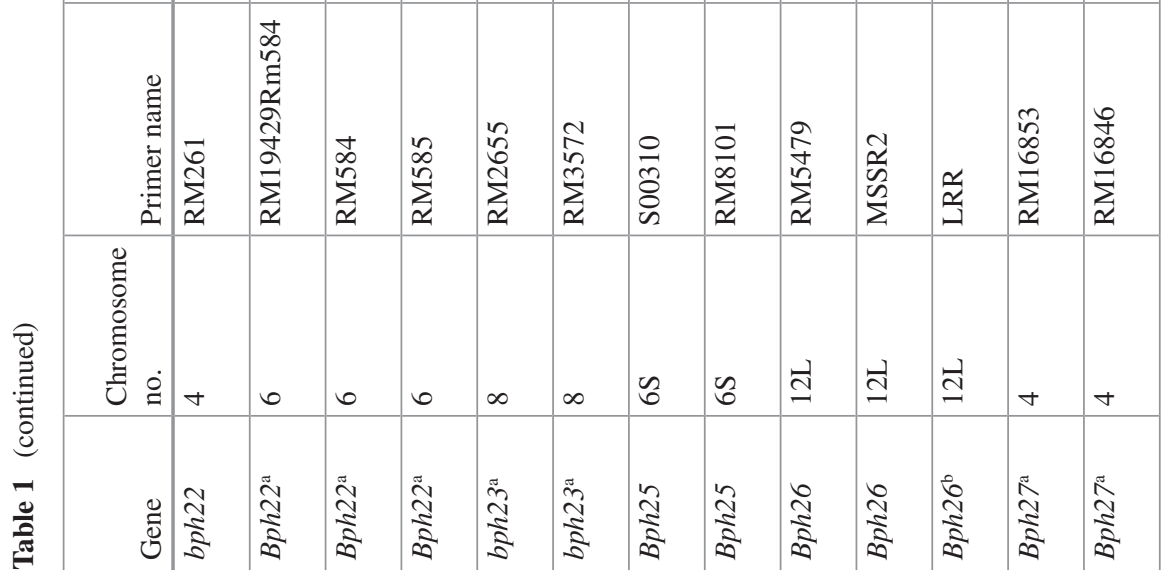




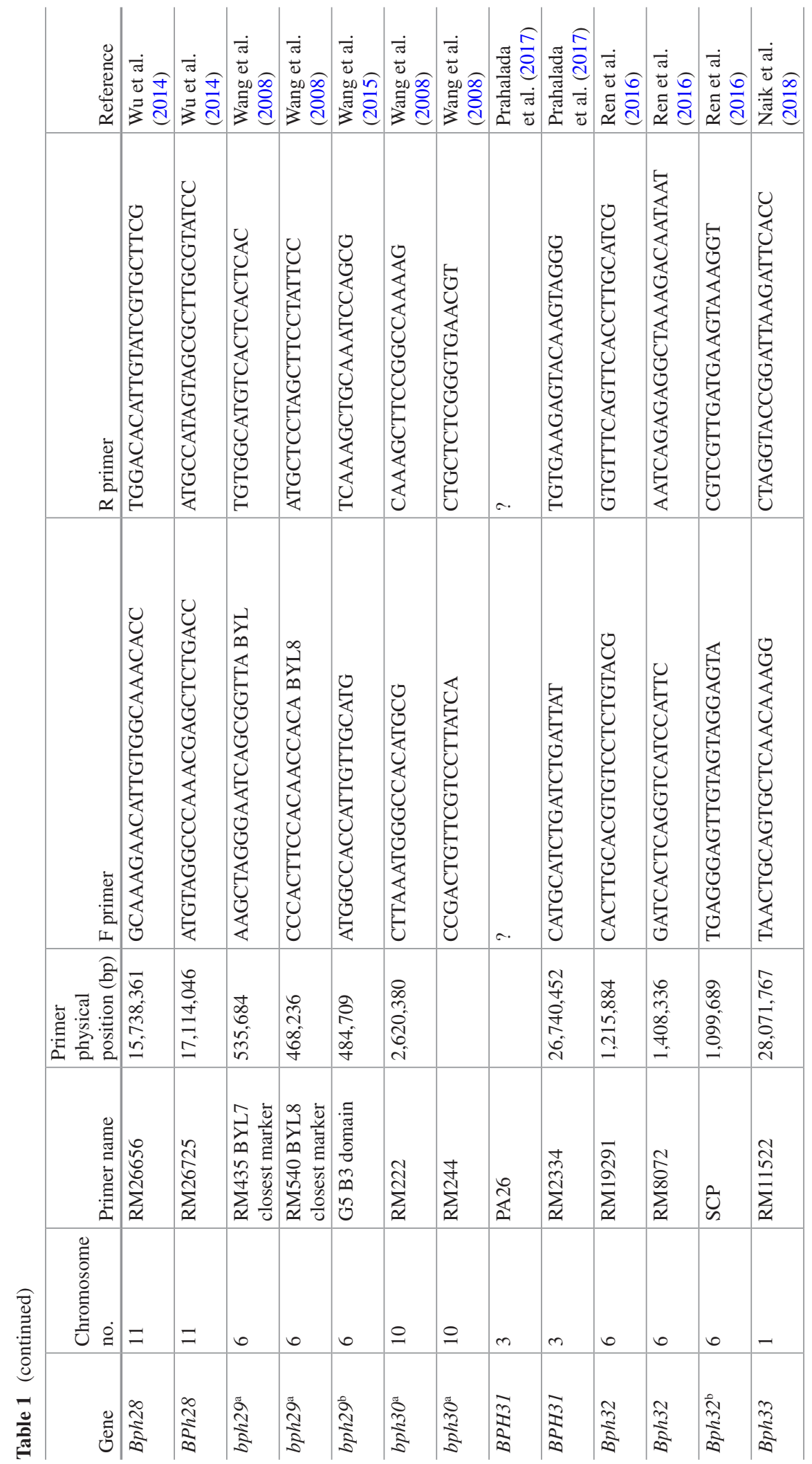




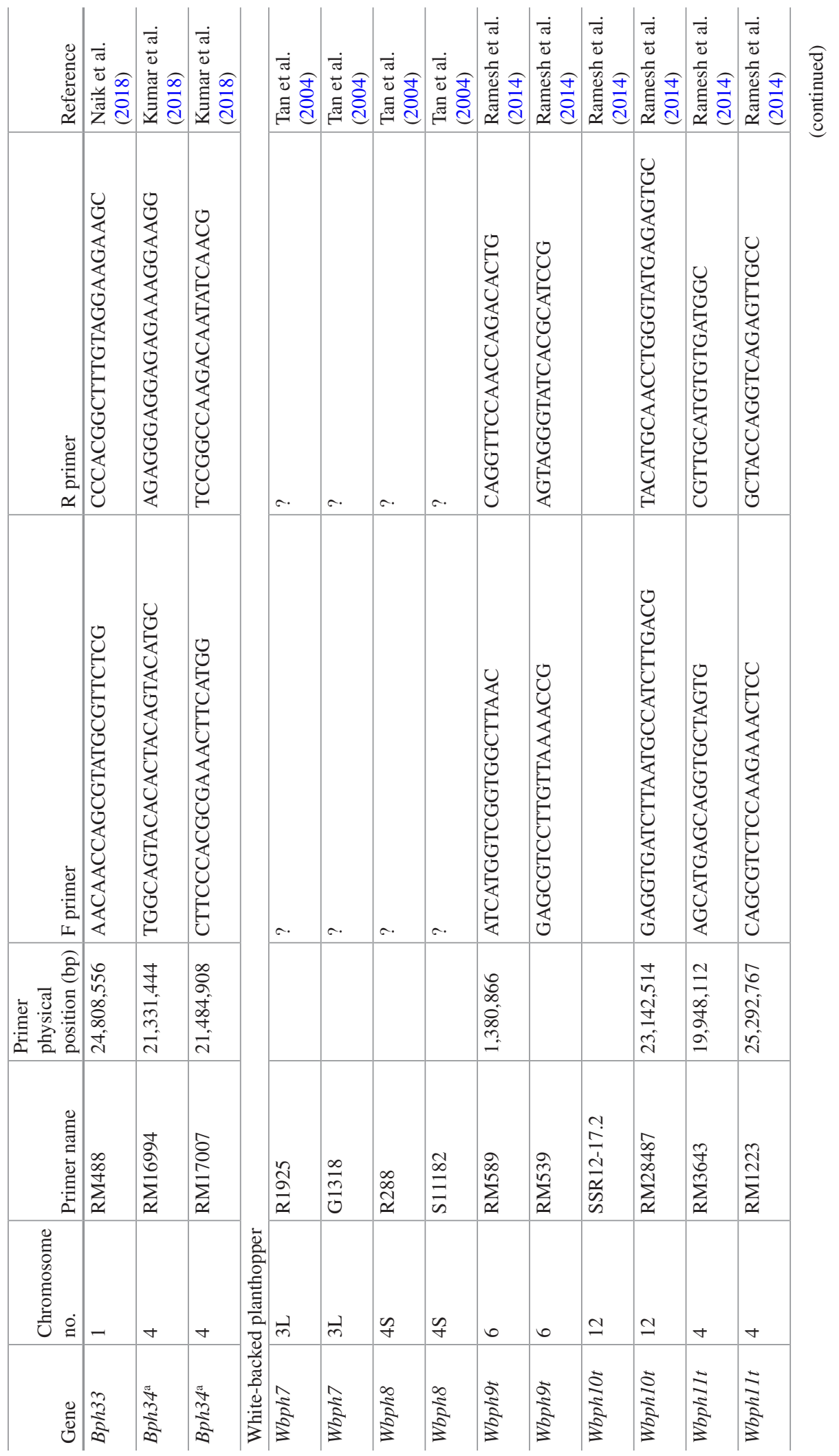




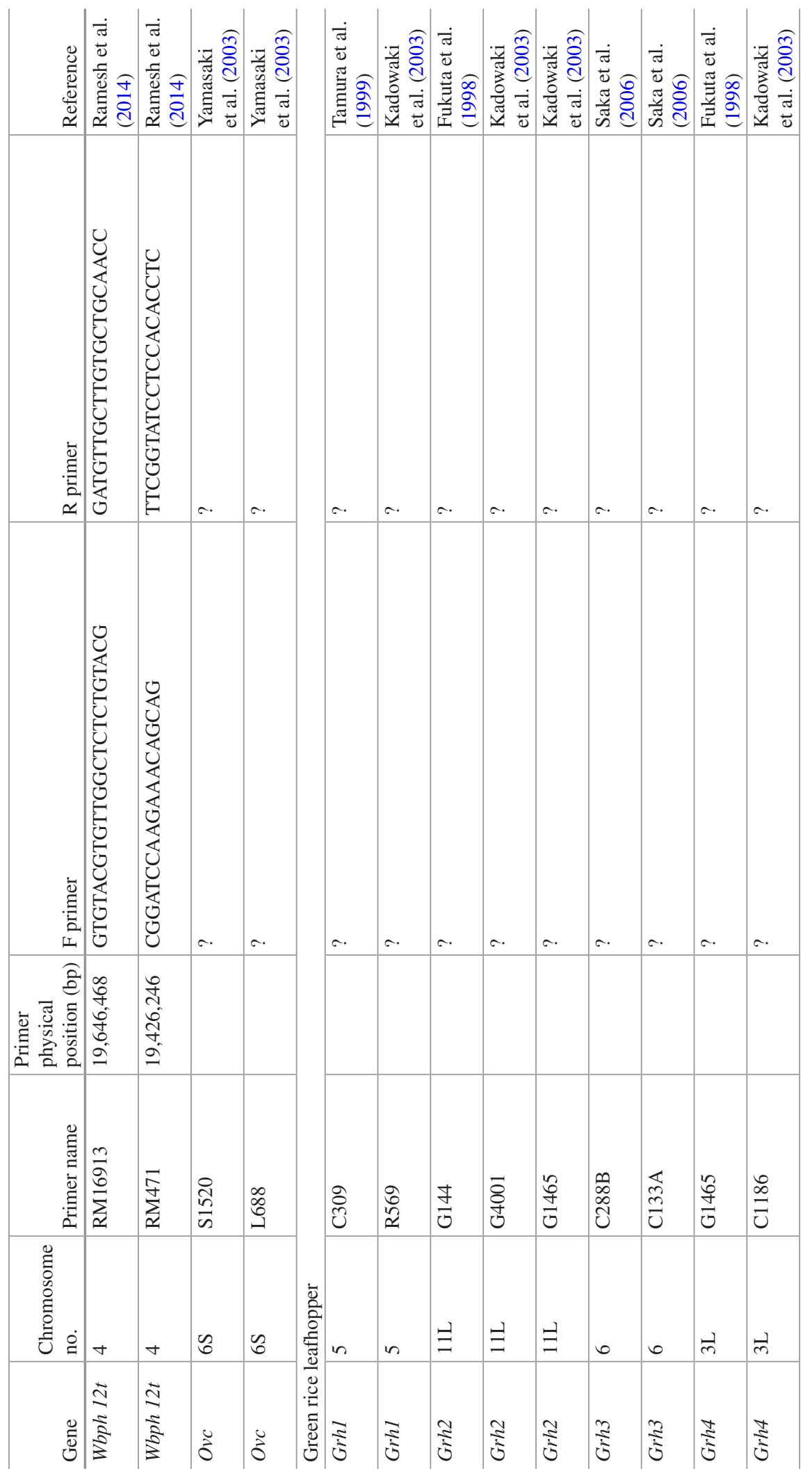




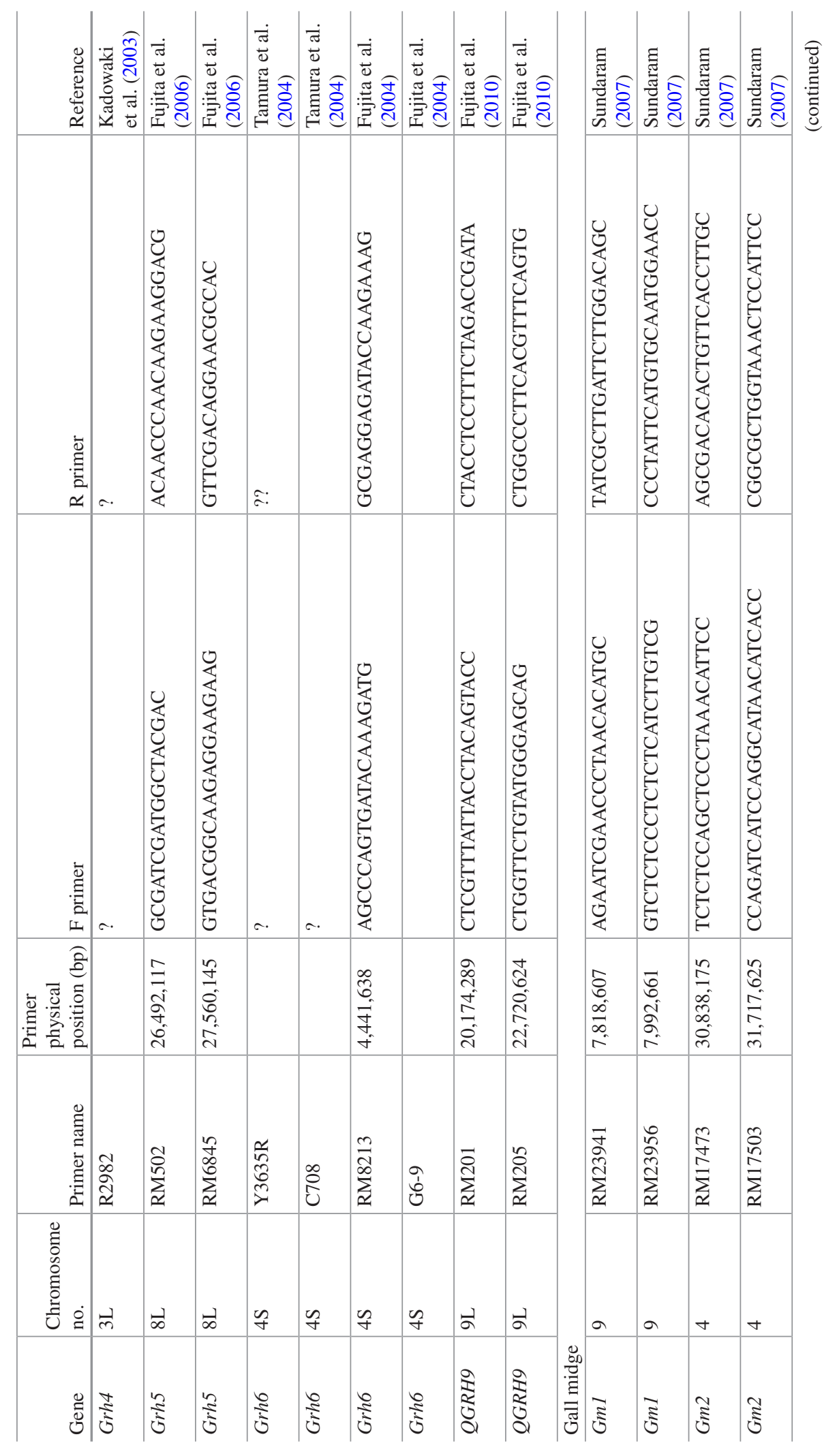




\begin{tabular}{|c|c|c|c|c|c|c|c|c|c|c|c|c|c|c|}
\hline $\begin{array}{l}8 \\
\frac{0}{0} \\
\frac{2}{2} \\
\frac{0}{2}\end{array}$ & 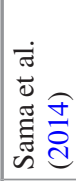 & 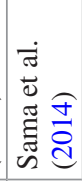 & 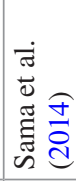 & 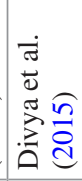 & 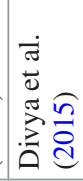 & 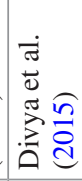 & 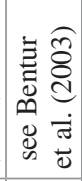 & 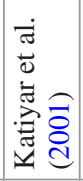 & 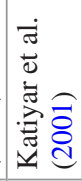 & 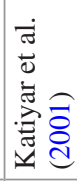 & 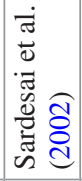 & 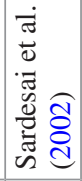 & 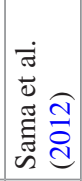 & 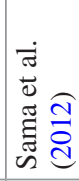 \\
\hline a & 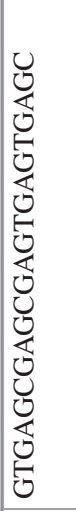 & 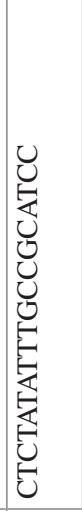 & 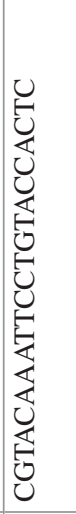 & 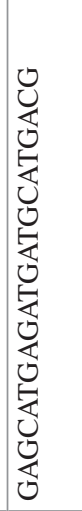 & 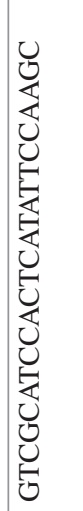 & 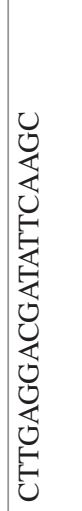 & a. & a. & a. & a. & a. & a. & 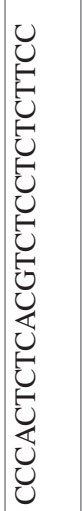 & 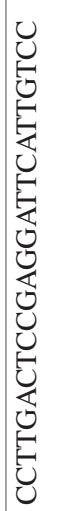 \\
\hline 离 & 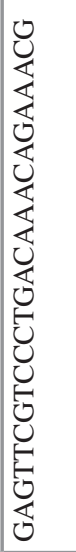 & 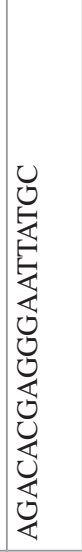 & 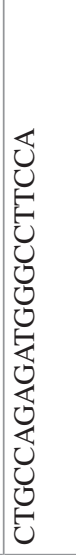 & 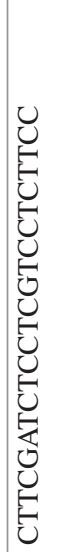 & 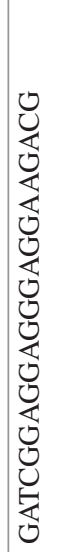 & 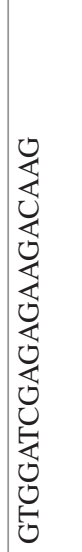 & a. & a. & a. & a. & a. & a. & 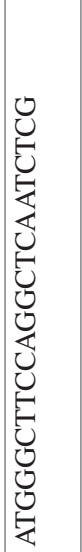 & 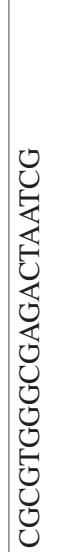 \\
\hline 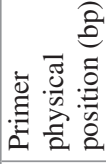 & 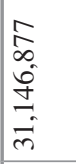 & $\begin{array}{l}8 \\
\vdots \\
n \\
0 \\
0 \\
i \\
n\end{array}$ & $\begin{array}{l}8 \\
8 \\
\delta \\
\vdots \\
\end{array}$ & $\begin{array}{l}\overline{0} \\
0 \\
i \\
7 \\
i \\
i\end{array}$ & $\begin{array}{l}\sqrt{n} \\
\tilde{a} \\
\infty \\
i \\
i\end{array}$ & $\begin{array}{l}m \\
\hat{n} \\
\infty \\
\infty \\
n \\
n\end{array}$ & & & & & & & 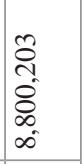 & 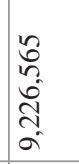 \\
\hline 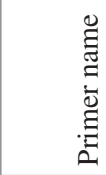 & 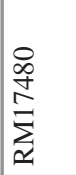 & 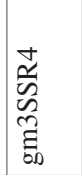 & 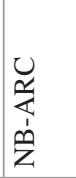 & 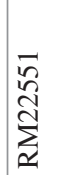 & 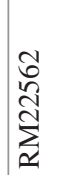 & 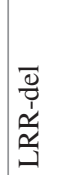 & $\begin{array}{l}\frac{\Delta}{0} \\
\frac{\infty}{0}\end{array}$ & $\frac{8}{0}$ & 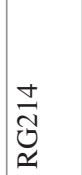 & 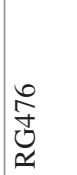 & $\begin{array}{l}\infty \\
2 \\
i \\
i \\
n\end{array}$ & $\infty$ & 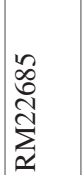 & 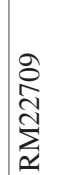 \\
\hline 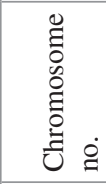 & t & $\theta$ & $\nabla$ & $\infty$ & $\infty$ & $\infty$ & 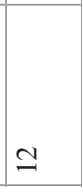 & $\nabla$ & $\nabla$ & $\nabla$ & $\nabla$ & $\nabla$ & $\infty$ & $\infty$ \\
\hline $\begin{array}{l}\mathscr{0} \\
0 \\
0\end{array}$ & בิ & בิ & స్ & 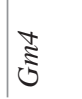 & $\underset{\Xi}{\mathbb{J}}$ & $\underset{\text { J }}{\stackrel{+}{\Xi}}$ & $\stackrel{n}{\stackrel{0}{5}}$ & ڤ్ర & ڤ్ & ڤ్ & $\widehat{\Xi}$ & $\widehat{\Xi}$ & $\stackrel{\infty}{\stackrel{ే}{\mathcal{J}}}$ & 胥 \\
\hline
\end{tabular}




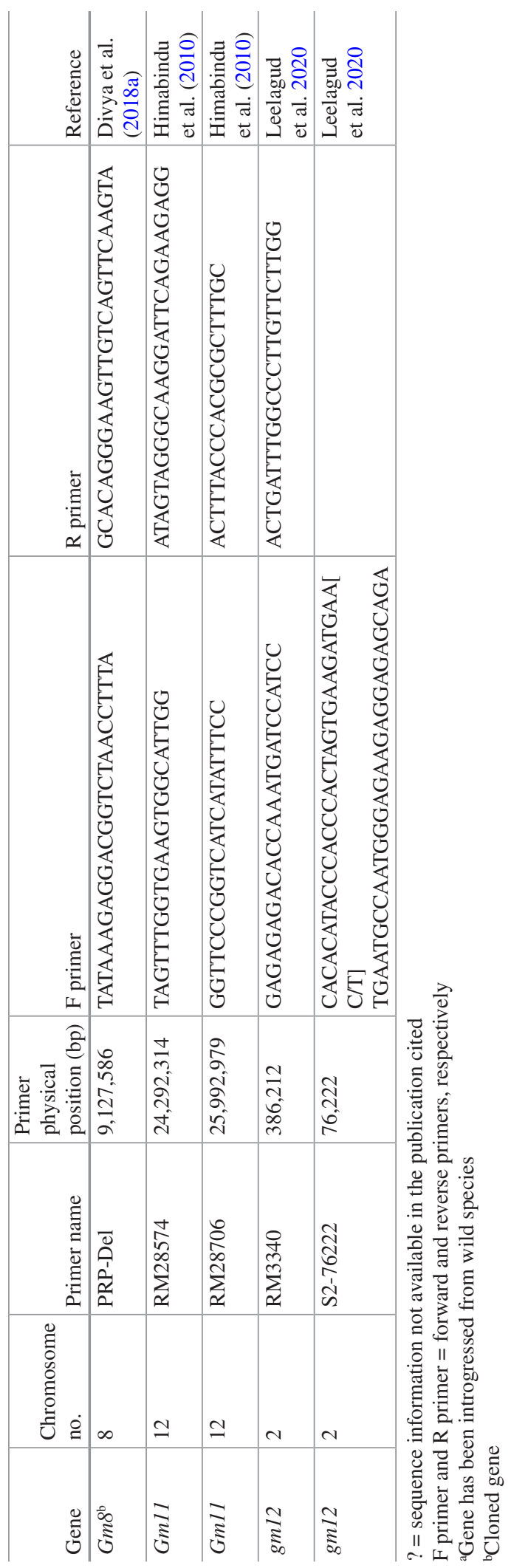


for pyramiding since it is a HR+ type and recessively inherited and has not been deployed so far in any variety.

Using Gm4 and Gm8, the research group at ICAR-IIRR (Abhilash Kumar et al. 2017) has developed gene-pyramided lines in the genetic background of the elite restorer line RPHR1005R (restorer line for the popular rice hybrid DRRH3) through marker-assisted breeding. In another such effort, the high-yielding rice variety Akshayadhan has been improved for its resistance against gall midge by targeted transfer of Gm4 and $G m 8$ genes. Sama et al. (2014) introduced the recessive gene gm3 into the genetic background of elite rice variety Improved Samba Mahsuri with the help of markers. In a recent report (Venkanna et al. 2018), two major resistance genes, gm3 and $G m 8$, have been pyramided in the genetic background of the finegrain-type rice variety Kavya, which already possesses $G m 1$. Now that closely linked markers/functional markers are available for all the major gall midge resistance genes, selected gene combinations can be pyramided into elite genetic backgrounds (Divya et al. 2018c) easily through marker-assisted breeding for developing durable multiARGM biotype-resistant rice cultivars/hybrids.

\subsection{Planthoppers and Leafhoppers}

Although more than 100 species of planthoppers (Delphacidae) and leafhoppers (Cicadellidae) are reported to feed on rice, three species of planthoppers (BPH, WBPH, and SBPH) have gained high economic importance since 2000 (Bentur and Viratkamath 2008). Likewise, of the leafhoppers, GLH, GRL, and ZLH are important. Although both groups consist of phloem sap feeders, planthoppers cause severe damage by feeding alone, leading to total death of plants, termed hopper burn. Both leafhoppers and planthoppers vector disease-causing viruses and cause indirect damage to the crop. The main virus diseases thus transmitted are rice ragged stunt, rice grassy stunt, and wilted stunt by $\mathrm{BPH}$; southern rice black-streaked dwarf by WBPH; stripe and black-streaked dwarf by SBPH; and rice tungro by several species of leafhoppers. In response to planthoppers and leafhoppers gaining importance, screening of rice germplasm for resistance began at the International Rice Research Institute (IRRI), Philippines, during the 1970s. Such initiatives were also taken up in other Asian rice-growing countries, leading to reports of a large number of resistance sources (IRRI 1979; Heinrichs et al. 1985; Heong and Hardy 2010). Several of these sources were selected for systematic studies on genetics of resistance, resulting in the identification of more than 38 major resistance genes against BPH, 14 against WBPH, 14 against GLH, six against GRL, and three against ZLH (Fujita et al. 2013; Ling and Weillin 2016; Du et al. 2020). Most of these genes are now tagged and mapped on different rice chromosomes and reliable molecular markers linked to these traits are available (Table 1). Marker-assisted selection as a tool for breeding for BPH resistance using a single gene or multiple genes is being 
reported (Liu et al. 2016; H Wang et al. 2016a; Y Wang et al. 2017b; Jiang et al. 2018). However, a few issues remain to be resolved. Several of the reported BPH Rgenes are not effective on the Indian subcontinent (Horgan et al. 2016); hence, more effective genes for the region need to be characterized from the reported sources. All the BPH Rgenes, except probably Bph3 (Liu et al. 2015), are not effective against WBPH. Since these two species are sympatric and are often under severe interspecific competition (Srinivasan et al. 2016), selecting for resistance against BPH alone may not be the right approach. But, efforts to tag, map, and clone WBPH resistance genes are few. Another limitation is the ability of BPH to quickly evolve virulent biotypes, especially if a single Rgene is deployed. Hence, gene pyramiding is suggested for durability. Ideally, undeployed genes with different mechanisms of resistance are the choice for pyramiding. Of the $13 \mathrm{BPH}$ Rgenes cloned, eight (Bph14, Bph26, Bph18, Bph9/1/7/10/21) represent the NBS-LRR family; proteins coded by these are located in the cytoplasm, while others are reported as lectin receptor kinases (Bph3, Bph15), B3 DNA-binding domain (bph29), or SCR domain protein (Bph32) coding (Ren et al. 2016; Y Zhao et al. 2016b; Du et al. 2020), which are membrane bound. It is suggested to combine two genes from these two classes (such as Bph14 + Bph15) to achieve durability (Jing et al. 2017).

\subsection{Other Pests}

Rice stem borers are ubiquitous insects representing Diopsidae (Diptera), Noctuidae, and Crambidae (Lepidoptera) families. Among several species of rice stem borers, YSB is considered the most economically important insect pest in almost all ricegrowing countries of Asia (Makkar and Bentur 2017). Larvae of YSB feed only on rice and can cause damage at both the vegetative (deadheart) and reproductive (whitehead) stages of the rice crop, with the latter being the main cause of yield loss (Savary et al. 2000). Because of the lack of highly resistant sources in rice germplasm explored so for, breeding for resistance or molecular mapping of resistance genes against YSB has not been encouraging (Bentur 2007). Nonetheless, rice varieties such as Vikas, Ratna, and Sasyasree have been developed and released in India with moderate YSB resistance. Most of these varieties have either TKM6 or W1263 as the source of resistance. Because of the lack of the desired level of resistance against YSB in the primary gene pool of rice, the secondary gene pool consisting of wild species of Oryza is being explored at IRRI, ICAR-IIRR, and other institutes. Chromosome segment substitution lines (CSSLs) need to be developed for different accessions of wild rice that can be evaluated for YSB resistance. Also, ethyl methanesulfonate (EMS) mutants of rice have been generated and evaluated at ICARIIRR and have shown encouraging results in preliminary evaluations. More extensive and concerted efforts in this direction have potential to identify novel sources of resistance that can be used by breeders and entomologists for understanding the resistance mechanisms and developing YSB-resistant rice cultivars. 


\section{Novel Approaches Through Genomics}

\subsection{RNAi Approach for Insect Resistance}

Transgenic crops harboring $B t$ endotoxin genes or other insecticidal protein-coding genes have shown tremendous potential for managing insect pests. Several of these genes have been used in transforming rice as described in the next section, although none of these have been commercially cultivated. As an alternative to this approach, RNA interference (RNAi) can be exploited, which has been well demonstrated for resistance induction in plants against viruses, bacteria, and nematodes. RNAi is an RNA-driven post-transcriptional homology-based gene-silencing mechanism through the mRNA degradation pathway present in all eukaryotic organisms. The RNAi is triggered by double-stranded RNAs (dsRNA), which are processed by the RNase-III-like Dicer protein to produce small interfering RNAs (siRNAs). The guide strand of siRNA directs an RNA-induced silencing complex (RISC) to the target mRNA (Fig. 1). The most important constituent of RISC is RNase protein Argonaute, which helps in the degradation of target mRNAs sharing homology with the guide strand of siRNA (Zamore et al. 2000). The double-stranded RNAs specific to key insect genes can be stably expressed in plant tissues fed on by the insect and that in turn can trigger the RNAi pathway to degrade the mRNAs transcribed by the key insect genes (Price and Gatehouse 2008; Agarwal et al. 2012).

Key genes in insects are identified as targets of RNAi, that is, genes coding developmental proteins, digestive enzymes, salivary gland proteins, nervous system regulatory proteins, proteins involved in host-insect interaction, hormone receptors, gut enzymes, and proteins involved in metabolism (Gatehouse 2008; Huvenne and Smagghe 2010; Agarwal et al. 2012; Kola et al. 2015).

Initial successes in experiments (Tomoyasu and Denell 2004; Turner et al. 2006) raised hope among researchers that RNAi could be another alternative and effective tool to develop insect resistance in crop plants. Initially, dsRNAs were delivered to the target insects either by injection or through artificial diet. Baum et al. (2007) demonstrated the effectiveness of host-plant-mediated production of dsRNA in crop protection. Transgenic maize plants producing insect-specific vacuolar $\mathrm{H}^{+}$ATPase dsRNAs had decreased root damage by western corn rootworm. In another similar report, Mao et al. (2007) generated transgenic Nicotiana tabacum and Arabidopsis thaliana targeting RNAi against the cytochrome P450 gene of Helicoverpa armigera, resulting in retarded larval growth of insects feeding on these modified hosts. The versatility of the application of RNAi against different insect orders and target genes shows the potential of RNAi for managing diverse crop pests (Terenius et al. 2011; Khajuria et al. 2015; Zhang et al. 2017). Recent reports suggest that the production of dsRNAs in chloroplasts, rather than in cytoplasm, can improve insect resistance significantly as long as dsRNAs can be stably produced in chloroplasts, which are devoid of RNAi machinery (Zhang et al. 2015; Jin et al. 2015; Bally et al. 2018). The first such RNAi-based DvSnf7 dsRNA-expressing maize crop targeting western corn rootworm is scheduled to be commercialized (Khajuria et al. 2018). Several research groups have been working on modifying the technology for its more efficient application. 


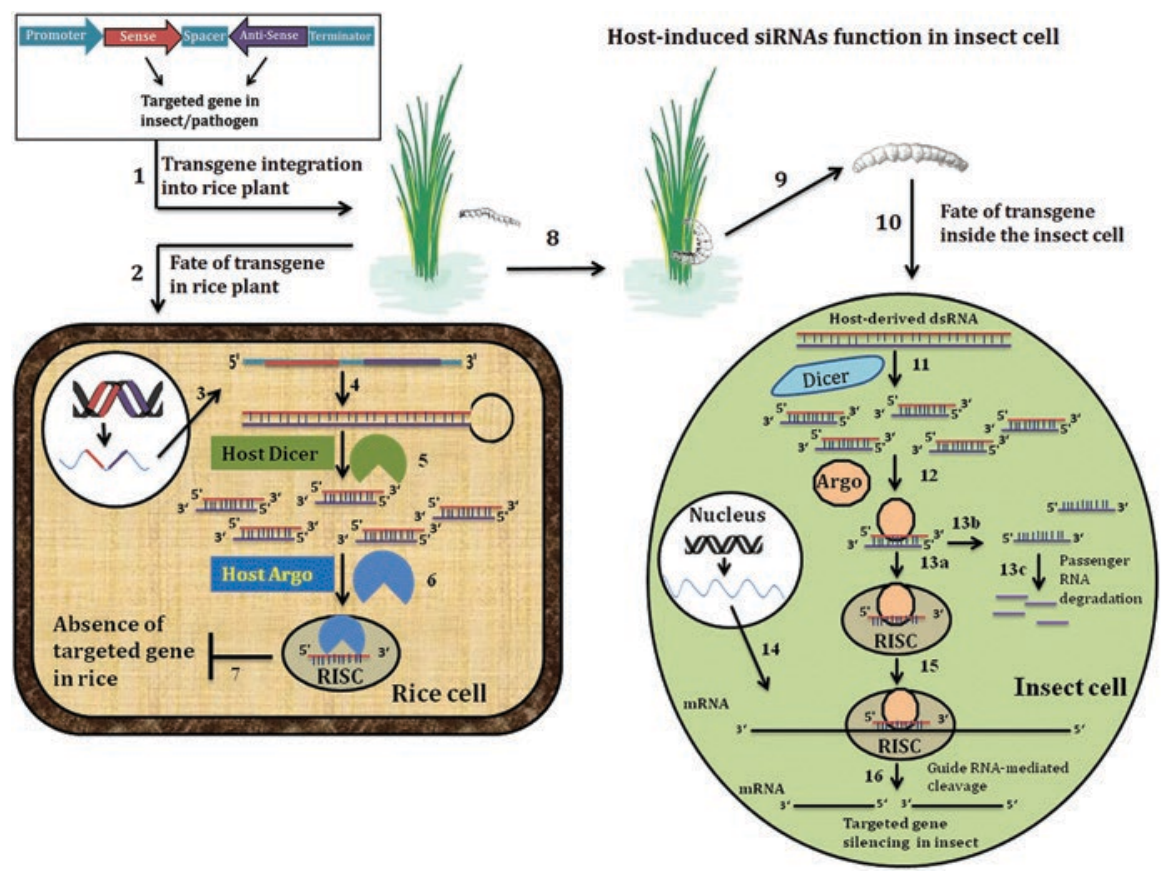

Fig. 1 Schematic representation of host-induced gene silencing in insects through siRNA approach. (1) Integration of insect gene-targeted siRNA cassette (transgene) into rice genome; (2) fate of transgene in rice cells; $(\mathbf{3})$ expression of transgene in rice cell generates the mRNA; (4) formations of dsRNA through self-complementation of transgene's sense and antisense strands in rice cell; (5) host Dicer-mediated specific cleavage of dsRNA leads to production of siRNAs in rice cell; (6) host-generated siRNAs processed by host Argonaute protein (the main component of RNA-induced silencing complex or RISC); (7) host-generated siRNAs are nonfunctional in rice cells due to absence of targeted gene; ( 8 and $\mathbf{9})$ host-synthesized dsRNAs/siRNAs transfer from rice plant to insect through feeding on rice tissues; (10) fate of transferred dsRNA/siRNAs in insect cells; (11) generation of siRNAs from dsRNA through insect Dicer-mediated cleavage; (12) the siRNAs are processed by insect Argonaute proteins/RISC complex; (13a) formation of activated RISC along with target-specific guide RNA; (13b and 13c) the passenger RNA is separated from guide RNA and degraded; (14) transcription of insect DNA resulted in the expression of targeted functional mRNA (transcript); (15) guide strand of siRNA helps in identification and binding of activated RISC to the targeted mRNA; (16) silencing of targeted gene expression by RISCmediated cleavage of corresponding mRNA

Application of the RNAi tool for insect resistance in rice is in the developmental phase. Most of the reports on RNAi in rice are centered on BPH (Zha et al. 2011; Zhou et al. 2013; Yu et al. 2014; Wang et al. 2018) and YSB (Renuka et al. 2017). RNAi has been used for functional genomics of glutathione $S$-transferase (GST) genes, which are involved in the degradation of toxins produced by host plants and insecticides. Injecting dsRNAs targeting the NIGSTe1 and N1GSTm2 genes into nymphs of $\mathrm{BPH}$ enhanced their sensitivity to chlorpyrifos but not to betacypermethrin. Through feeding assays and stable expression of NlEcR (ecdysone receptor gene) targeting dsRNAs in rice, Yu et al. (2014) showed significant downregulation of target gene expression and a decrease in the number of offspring 
produced by BPH adults. Likewise, Zha et al. (2011) targeted three midgut genes, carboxypeptidase (Nlcar), hexose transporter (NlHT1), and trypsin-like serine protease (Nltry). L Zhao et al. (2016a) aimed at trehalase genes involved in chitin biosynthesis and degradation. Wang et al. (2018) aimed at the calmodulin gene, Waris et al. (2018) aimed at the chemosensory protein 8 (CSP8) gene, and Zhu et al. (2017b) studied the function of the ribosomal protein gene (NIRPL5) using an RNAi tool. Pan et al. (2018) used RNAi to knock down 135 CP (chitin and cuticular protein) genes by injecting specific dsRNAs and showed that 32 CPs are necessary for normal egg production and development. Li et al. (2015) suggested that dsRNAs are stable under diverse environments and can be absorbed by roots of crop plants. This study provides scope to use dsRNAs as biopesticides. The above-cited studies are laying the foundation for the development of RNAi as a tool for managing rice pests such as BPH.

Kola et al. (2016) showed by feeding YSB larvae with dsRNA of cytochrome P450 derivative $(C Y P O)$ and amino peptidase $\mathrm{N}(A P N)$ that expression of target genes decreased and resulted in increased mortality of larvae after 12-15 days. Similarly, Zeng et al. (2018) knocked down three chemosensory protein (CSP) genes in rice leaffolder ( $C$. medinalis) through injection of dsRNAs, which downregulated insect response to the specific chemicals. He et al. (2018), in contrast, overexpressed striped stem borer-derived miR-14 microRNA in rice, which resulted in a high resistance against the pest.

\subsection{Genome Editing Approach for Insect Resistance}

Genome editing tools enable us to edit the genome or specific genes of an organism by addition/deletion or replacement of nucleotides with high precision and with few off-target effects. Because of its simplicity and wider applicability, genome editing is being practiced in many laboratories for functional genomics and trait improvement. In agriculture, the technology has immense potential to improve yield and abiotic and biotic stress tolerance of crops. Also, the technology does not attract many concerns regarding biosafety regulators, specifically in the case of deletion of nucleotides. Most of the research on genome editing has been focused on functional genomics, trait discovery, and improvement in plants (Arora and Narula 2017; Yin et al. 2017; Aglawe et al. 2018).

The use of genome editing techniques for pest control in plants has just been hypothesized. Zuo et al. (2017) created a mutation in Spodoptera exigua with CRISPR/Cas9 technology, which resulted in a mutant insect with high resistance against chlorantraniliprole, cyantraniliprole, and flubendiamide insecticides. To demonstrate the role of the cadherin gene in developing resistance against $B t$ toxin, the gene was edited by CRISPR/Cas9 in Helicoverpa armigera. The mutant strain of the insect showed high resistance to Cry1Ac (J Wang et al. 2016b). The pheromone-binding protein 1 (PBP1) gene of $H$. armigera was mutated and the mutant male adults showed impaired responses to sex pheromone (ZF Ye et al. 
2017b). Dong et al. (2017) mutated PBP1 and PBP3 genes in striped stem borer to demonstrate their function. Biogenesis of the lysosome-related organelles complex 1 subunit 2 (BLOS2) gene of Spodoptera litura was edited, which resulted in the disappearance of the yellow strips and white spots on the larval integument (Zhu et al. 2017a). Similarly, when the abdominal-A (Slabd-A) gene of S. litura was mutated, it resulted in ectopic pigmentation and anomalous segmentation during the larval stage (Bi et al. 2016). Recently, Xue et al. (2018) edited two eye pigmentation genes in $\mathrm{BPH}$, resulting in bright red compound eyes.

Although most of these reports showed successful application of CRISPR-based genome editing technology for functional genomics of insect genes, its use for incorporating and enhancing pest resistance in crops is yet to be realized. It is possible to derive genome editing-mediated resistance against insects by targeting either the host genes or the gene drive in insect populations. There is a dearth of information with regard to insect-susceptibility genes of host plants, specifically in rice. The recessive resistance genes identified so far are likely to represent nonfunctional susceptibility genes and hence the need for more studies to characterize such candidate genes, which represent ideal targets for genome editing to develop new sources of resistance. Alternatively, novel resistance alleles can be created in susceptible rice cultivars either by replacement of a few nucleotides/motifs/domains or by editing of specific bases or transfer of a complete gene. However, precise replacement of nucleotides, base editing, and insertion of a gene through CRISPR technology are relatively complex at this stage and it may require a few more years for researchers in not-so-sophisticated laboratories to be able to use this technology.

Gene drive is another highly potential technology that can be exploited to promote the inheritance of CRISPR-generated mutated alleles or any other DNA sequence by sexual reproduction, which allows a rapid spread of genes among the insect population. Even the whole CRISPR machinery, that is, Cas9 mRNA and specific sgRNAs, can be spread into insect populations via a gene drive. Besides controlling the insect population, it can decrease vector-borne virus diseases such as rice tungro disease. However, its application requires a thorough public debate among scientists, policymakers, and regulators and other stakeholders (CourtierOrgogozo et al. 2017). In addition, the rapid advancement in genome editing technologies will facilitate the functional analysis of insect genes, which would indirectly help in developing more effective strategies for achieving effective and durable biotic stress resistance in crops.

\section{Transgenic Approach Through Gene Transfer}

As naturally occurring resistance to lepidopteran pests of rice is yet to be identified/ discovered (e.g., stem borers and leaffolders; Schuler et al. 1998), transgenesis offers a potent, immediate, cost-effective, and environment-friendly option for control of these pests through access and use of resistance from unrelated sources (i.e., nonrice sources). Fortunately, tissue culture and genetic transformation protocols 
are well established in rice and many bacterial-derived insecticidal proteins have been deployed in rice through transgenic breeding (Sundaram et al. 2013). Bt genes derived from the soil bacterium Bacillus thuringiensis have been the most successful group of related genes used commercially for genetic transformation of many crop plants, including rice. $B t$ genes encode for insecticidal proteins that are filled in crystalline inclusion bodies produced by the bacterium upon sporulation (e.g., Cry protein) or expressed during bacterial growth (e.g., Vip proteins). In addition, several research groups are assessing the potential of using non- $B t$ insecticidal proteins such as lectins (carbohydrate-binding proteins), proteinase inhibitors, ribosome-inactivating proteins, secondary plant metabolites, small RNA viruses, etc. (Makkar and Bentur 2017).

\subsection{Development of Transgenic Rice for Insect Resistance}

The crystal insecticidal proteins (Cry toxins or delta-endotoxins) encoded by $B t$ genes are known to possess high toxicity to lepidopteran pests (Cohen et al. 2000), Dipterans (Andrews et al. 1987), and Coleopterans (Krieg et al. 1983; Herrnstadt et al. 1986) but are nontoxic to other groups of insects, other animals, and humans. Fujimoto et al. (1993) reported the first transformation of rice with a $B t$ gene. Many reports on the development and evaluation of $B t$ rice lines have since appeared (see review by High et al. 2004; Chen et al. 2006). Rice lines expressing CrylAa, CrylAb, CrylAc, CrylAb/CrylAc fusion gene, CrylB, CrylC, Cry2A, and a pyramid of CrylAc with $C r y 2 A$, under the control of various constitutive and conditional promoters, have been shown to confer resistance to stem borers, leaffolders, and other foliage-feeding lepidopteran insects (Table 2). Several rice lines expressing insecticidal genes with anti-lepidopteran activity using Cry genes (CrylAa, CrylAb, CrylAc, CrylAb/Ac, CrylC, Cry2A), CpTI (cowpea trypsin inhibitor), Vip (vegetative insecticidal protein), etc., have been reported. Various transgenic Bt (CrylAb, CrylAc) rice varieties (IR64, Karnal Local, etc.) resistant to YSB have been produced in India (Khanna and Raina 2002; Ramesh et al. 2004a). Pradhan et al. (2016) deployed a vegetative insecticidal protein (vip) in the genetic background of Swarna and demonstrated that the transgenic rice is resistant to multiple lepidopteran pests such as yellow stem borer, leaffolder, and rice horny caterpillar. Field evaluation and validation of transgenic rice possessing CrylA (Shu et al. 2000; Tu et al. 2000) and synthetic CrylAb (Shu et al. 2002) have been reported from China. Field trials of $B t$ rice have also been conducted in Pakistan (Bashir et al. 2005; Mahmood-urRahman et al. 2007), Spain (Breitler et al. 2004), Iran (James 2005), and India (Bunsha 2006). Iran was the first country to release $B t$ rice for commercial cultivation in 2004 (Makkar and Bentur 2017). China permitted the commercial production of $B t$ rice lines Huahui No. 1 (CMS restorer line) and $B t$ Shanyou 63 (a hybrid of Huahui No. 1 and Zhenshan 97A, a CMS line), both lines expressing CrylAb/Ac fusion gene (Chen et al. 2011), but cultivation was discontinued afterward. Currently, no $B t$ rice is grown in any country across the world, including China, although 
Table 2 List of transgenes used in rice transformation to provide insect resistance

\begin{tabular}{|c|c|c|c|c|c|}
\hline S. No. & $\begin{array}{l}\text { Transgene(s) } \\
\text { deployed }\end{array}$ & $\begin{array}{l}\text { Recipient rice variety/ } \\
\text { genotype }\end{array}$ & $\begin{array}{l}\text { Promoter } \\
\text { deployed }\end{array}$ & $\begin{array}{l}\text { Reported } \\
\text { resistant } \\
\text { against }\end{array}$ & Reference(s) \\
\hline \multicolumn{6}{|c|}{ Lepidopteran pests } \\
\hline 1 & cry $1 A b$ & IR58 (indica rice) & CaMV35S & $\begin{array}{l}\text { Yellow stem } \\
\text { borer, striped } \\
\text { stem borer, } \\
\text { leaffolder }\end{array}$ & $\begin{array}{l}\text { Wunn et al. } \\
\text { (1996) }\end{array}$ \\
\hline 2 & $\begin{array}{l}\text { PINII (potato } \\
\text { proteinase } \\
\text { inhibitor) }\end{array}$ & Japonica rice & - & $\begin{array}{l}\text { Pink stem } \\
\text { borer }\end{array}$ & $\begin{array}{l}\text { Duan et al. } \\
(1996)\end{array}$ \\
\hline 3 & $\operatorname{cry} 1 A b$ & Japonica, Taipei 309 & $\begin{array}{l}\text { Rice actin-1 } \\
\text { promoter }\end{array}$ & $\begin{array}{l}\text { Yellow stem } \\
\text { borer }\end{array}$ & $\begin{array}{l}\text { Wu et al. } \\
(1997 a)\end{array}$ \\
\hline 4 & $\begin{array}{l}\text { cry } 1 A, \text { cowpea } \\
\text { proteinase } \\
\text { inhibitor gene }\end{array}$ & $\begin{array}{l}\text { Japonica, Taipei 309, } \\
\text { and Taipei 85-93. } \\
\text { Indica, Minghui 63, } \\
\text { and Qingliu Rai }\end{array}$ & - & $\begin{array}{l}\text { Yellow stem } \\
\text { borer }\end{array}$ & $\begin{array}{l}\text { Wu et al. } \\
(1997 b)\end{array}$ \\
\hline 5 & cry $1 A C$ & IR64 (indica rice) & $\begin{array}{l}\text { Maize } \\
\text { ubiquitin } 1 \\
\text { promoter }\end{array}$ & $\begin{array}{l}\text { Yellow stem } \\
\text { borer }\end{array}$ & $\begin{array}{l}\text { Nayak et al. } \\
\text { (1997) }\end{array}$ \\
\hline 6 & $\begin{array}{l}\operatorname{cry} 1 A a, \text { cry } 1 A c, \\
\operatorname{cry} 2 A, \operatorname{cry} 1 C\end{array}$ & Indica, japonica & - & $\begin{array}{l}\text { Yellow stem } \\
\text { borer }\end{array}$ & $\begin{array}{l}\text { Lee et al. } \\
(1997)\end{array}$ \\
\hline 7 & crylAb & $\begin{array}{l}\text { Aromatic rice, Tarom } \\
\text { molaii }\end{array}$ & - & $\begin{array}{l}\text { Yellow stem } \\
\text { borer }\end{array}$ & $\begin{array}{l}\text { Ghareyazie } \\
\text { et al. (1997) }\end{array}$ \\
\hline 8 & $\operatorname{cry} 2 A$ & $\begin{array}{l}\text { Basmati } 370 \text { and M7 } \\
\text { (indica rice) }\end{array}$ & $\begin{array}{l}\text { CaMV35S } \\
\text { promoter }\end{array}$ & $\begin{array}{l}\text { Yellow stem } \\
\text { borer, } \\
\text { leaffolder }\end{array}$ & $\begin{array}{l}\text { Maqbool et al. } \\
\text { (1998) }\end{array}$ \\
\hline 9 & crylAb & $\begin{array}{l}\text { Indica and japonica } \\
\text { rice }\end{array}$ & - & $\begin{array}{l}\text { Yellow stem } \\
\text { borer }\end{array}$ & $\begin{array}{l}\text { Datta et al. } \\
(1998)\end{array}$ \\
\hline 10 & $\begin{array}{l}\text { cry } 1 A b, \text { crylAc, } \\
\text { hph, gus genes }\end{array}$ & Japonica rice & $\begin{array}{l}\text { Maize } \\
\text { ubiquitin } \\
\text { promoter, the } \\
\text { CaMV 35S } \\
\text { promoter, } \\
\text { and the } \\
\text { Brassica } \\
\text { Bp10 gene } \\
\text { promoter }\end{array}$ & $\begin{array}{l}\text { Yellow stem } \\
\text { borer, striped } \\
\text { stem borer }\end{array}$ & $\begin{array}{l}\text { Cheng et al. } \\
(1998)\end{array}$ \\
\hline 11 & cry $1 A b$ & $\begin{array}{l}\text { Maintainer line } \\
\text { IR68899B }\end{array}$ & $\begin{array}{l}35 \mathrm{~S} \\
\text { constitutive } \\
\text { promoter }\end{array}$ & $\begin{array}{l}\text { Yellow stem } \\
\text { borer }\end{array}$ & $\begin{array}{l}\text { Alam et al. } \\
(1999)\end{array}$ \\
\hline 12 & $c r y 1 A b$ & Vaidehi (indica rice) & - & $\begin{array}{l}\text { Yellow stem } \\
\text { borer }\end{array}$ & $\begin{array}{l}\text { Alam et al. } \\
\text { (1998) }\end{array}$ \\
\hline 13 & cry $1 A b$ & PR16 and PR18 & $\begin{array}{l}\text { Maize } \\
\text { ubiquitin } \\
\text { promoter }\end{array}$ & $\begin{array}{l}\text { Yellow stem } \\
\text { borer }\end{array}$ & $\begin{array}{l}\text { Ye et al. } \\
(2000)\end{array}$ \\
\hline
\end{tabular}


Table 2 (continued)

\begin{tabular}{|c|c|c|c|c|c|}
\hline S. No. & $\begin{array}{l}\text { Transgene(s) } \\
\text { deployed }\end{array}$ & $\begin{array}{l}\text { Recipient rice variety/ } \\
\text { genotype }\end{array}$ & $\begin{array}{l}\text { Promoter } \\
\text { deployed }\end{array}$ & $\begin{array}{l}\text { Reported } \\
\text { resistant } \\
\text { against }\end{array}$ & Reference(s) \\
\hline 14 & $\operatorname{cry} 1 A b, \operatorname{cry} 1 A c$ & $\begin{array}{l}\text { Minghui } 63 \text { (indica } \\
\text { CMS restorer line) } \\
\text { and its derived hybrid } \\
\text { rice Shanyou } 63\end{array}$ & $\begin{array}{l}\text { Rice actin-1 } \\
\text { promoter }\end{array}$ & $\begin{array}{l}\text { Yellow stem } \\
\text { borer and } \\
\text { leaffolder }\end{array}$ & $\begin{array}{l}\text { Tu et al. } \\
\text { (2000) }\end{array}$ \\
\hline 15 & crylAb & $\begin{array}{l}\text { KMD1 (japonica elite } \\
\text { line) }\end{array}$ & - & $\begin{array}{l}\text { Yellow stem } \\
\text { borer }\end{array}$ & $\begin{array}{l}\text { Shu et al. } \\
(2000)\end{array}$ \\
\hline 16 & $\begin{array}{l}\text { cry } 1 A, \text { cry } 1 A b, \\
\text { cry } 1 A c, \text { cry } 1 c \\
\text { and } \text { cry } 2 A\end{array}$ & Indica rice & - & $\begin{array}{l}\text { Yellow stem } \\
\text { borer }\end{array}$ & $\begin{array}{l}\text { Intikhab et al. } \\
(2000)\end{array}$ \\
\hline 17 & cry $1 A b, X a 21$ & $\begin{array}{l}\text { Pusa Basmati } 1 \\
\text { (indica rice) }\end{array}$ & - & $\begin{array}{l}\text { Yellow stem } \\
\text { borer, } \\
\text { Bacterial } \\
\text { blight disease }\end{array}$ & $\begin{array}{l}\text { Gosal et al. } \\
(2000)\end{array}$ \\
\hline 18 & CRY1AB & KMD1 and KMD2 & - & $\begin{array}{l}\text { Yellow stem } \\
\text { borer, striped } \\
\text { stem borer }\end{array}$ & $\begin{array}{l}\text { Ye et al. } \\
(2001)\end{array}$ \\
\hline 19 & $\begin{array}{l}\text { cry } 1 A c, \text { cry } 2 A, \\
\text { snowdrop lectin } \\
\text { gna }\end{array}$ & $\begin{array}{l}\text { M7 and Basmati } 370 \\
\text { (indica rice varieties) }\end{array}$ & $\begin{array}{l}\text { Maize } \\
\text { ubiquitin-1 } \\
\text { promoter, } \\
\text { CaMV 35S } \\
\text { promoter }\end{array}$ & $\begin{array}{l}\text { Yellow stem } \\
\text { borer, } \\
\text { leaffolder, } \\
\text { and BPH }\end{array}$ & $\begin{array}{l}\text { Maqbool et al. } \\
\text { (2001) }\end{array}$ \\
\hline 20 & crylAb & IR64 (indica rice) & - & $\begin{array}{l}\text { Yellow stem } \\
\text { borer }\end{array}$ & $\begin{array}{l}\text { Maiti et al. } \\
(2001)\end{array}$ \\
\hline 21 & $\begin{array}{l}\text { Spider } \\
\text { insecticidal gene }\end{array}$ & $\begin{array}{l}\text { Xiushuill and } \\
\text { Chunjiang } 11\end{array}$ & - & $\begin{array}{l}\text { Leaffolder } \\
\text { and striped } \\
\text { stem borer }\end{array}$ & $\begin{array}{l}\text { Huang et al. } \\
\text { (2001) }\end{array}$ \\
\hline 22 & crylAc gene & Minghui 81 & $\begin{array}{l}\text { Maize } \\
\text { ubiquitin-1 } \\
\text { promoter }\end{array}$ & $\begin{array}{l}\text { Striped stem } \\
\text { borer }\end{array}$ & $\begin{array}{l}\text { Zeng et al. } \\
(2002)\end{array}$ \\
\hline 23 & crylAc gene & $\begin{array}{l}\text { Pusa Basmati-1, } \\
\text { IR64, and Karnal } \\
\text { Local (indica rice) }\end{array}$ & $\begin{array}{l}\text { Maize } \\
\text { ubiquitin-1 } \\
\text { promoter }\end{array}$ & $\begin{array}{l}\text { Yellow stem } \\
\text { borer }\end{array}$ & $\begin{array}{l}\text { Khanna and } \\
\text { Raina (2002) }\end{array}$ \\
\hline 24 & $\begin{array}{l}\text { Bt fusion gene } \\
\text { (for insect } \\
\text { resistance), } \\
\text { Xa21 gene (for } \\
\text { BLB), chitinase } \\
\text { gene (sheath } \\
\text { blight) }\end{array}$ & IR72 (indica rice) & - & $\begin{array}{l}\text { Yellow stem } \\
\text { borer, } \\
\text { bacterial } \\
\text { blight } \\
\text { disease, } \\
\text { sheath blight } \\
\text { disease } \\
\end{array}$ & $\begin{array}{l}\text { Datta et al. } \\
\text { (2002) }\end{array}$ \\
\hline 25 & $\begin{array}{l}\text { Chimeric } B t \\
\text { gene, } \text { cry } 1 A b ; \\
\text { cry } 1 A b / c r y 1 A c \\
\text { fusion gene }\end{array}$ & $\begin{array}{l}\text { IR68899B and } \\
\text { IR68897B } \\
\text { (maintainer lines), } \\
\text { MH63 and BR827- } \\
\text { 35R (restorer lines) }\end{array}$ & $\begin{array}{l}35 \mathrm{~S} \text { and } \\
\text { PEPC } \\
\text { promoters; } \\
\text { actin 1 } \\
\text { promoter }\end{array}$ & $\begin{array}{l}\text { Yellow stem } \\
\text { borer, } \\
\text { leaffolder }\end{array}$ & $\begin{array}{l}\text { Balachandran } \\
\text { et al. (2002) }\end{array}$ \\
\hline
\end{tabular}


Table 2 (continued)

\begin{tabular}{|c|c|c|c|c|c|}
\hline S. No. & $\begin{array}{l}\text { Transgene(s) } \\
\text { deployed }\end{array}$ & $\begin{array}{l}\text { Recipient rice variety/ } \\
\text { genotype }\end{array}$ & $\begin{array}{l}\text { Promoter } \\
\text { deployed }\end{array}$ & $\begin{array}{l}\text { Reported } \\
\text { resistant } \\
\text { against }\end{array}$ & Reference(s) \\
\hline 26 & $\begin{array}{l}\text { crylAb, } \\
\text { snowdrop lectin } \\
\text { gna }\end{array}$ & $\begin{array}{l}\text { Rajalele (javanica } \\
\text { progenies) }\end{array}$ & - & $\begin{array}{l}\text { Yellow stem } \\
\text { borer, } \\
\text { planthoppers }\end{array}$ & $\begin{array}{l}\text { Slamet et al. } \\
\text { (2003) }\end{array}$ \\
\hline 27 & crylAc & $\begin{array}{l}\text { IR64, Pusa } \\
\text { Basmati-1, and } \\
\text { Karnal Local (indica } \\
\text { rice) }\end{array}$ & $\begin{array}{l}\text { Maize } \\
\text { ubiquitin } \\
\text { promoter }\end{array}$ & $\begin{array}{l}\text { Yellow stem } \\
\text { borer }\end{array}$ & $\begin{array}{l}\text { Raina et al. } \\
\text { (2003) }\end{array}$ \\
\hline 28 & cry $1 A c$, cry $2 A$ & Basmati (indica rice) & $\begin{array}{l}\text { PEPC } \\
\text { promoter and } \\
\text { PB } 10 \\
\text { (pollen- } \\
\text { specific) } \\
\text { promoter }\end{array}$ & $\begin{array}{l}\text { Yellow stem } \\
\text { borer }\end{array}$ & $\begin{array}{l}\text { Husnain et al. } \\
\text { (2003) }\end{array}$ \\
\hline 29 & crylAc, Xa21 & $\begin{array}{l}\text { Pusa Basmati-1 } \\
\text { (indica rice) }\end{array}$ & - & $\begin{array}{l}\text { Yellow stem } \\
\text { borer, } \\
\text { bacterial } \\
\text { blight }\end{array}$ & $\begin{array}{l}\text { Gosal et al. } \\
\text { (2003) }\end{array}$ \\
\hline 30 & $\begin{array}{l}C R Y 1 A B, \\
C R Y 1 A C \text { genes; } \\
\text { bar gene for } \\
\text { herbicide } \\
\text { resistance }\end{array}$ & $\begin{array}{l}\text { IR58025A, } \\
\text { IR58025B, and } \\
\text { Vajram (indica rice) }\end{array}$ & $\begin{array}{l}\text { Maize } \\
\text { ubiquitin } \\
\text { promoter, } \\
\text { CaMV 35S } \\
\text { promoter } \\
\text { (for BAR } \\
\text { gene) }\end{array}$ & $\begin{array}{l}\text { Yellow stem } \\
\text { borer }\end{array}$ & $\begin{array}{l}\text { Ramesh et al. } \\
(2004 b)\end{array}$ \\
\hline 31 & cry $1 B$, cry $1 A a$ & Ariete and Senia & $\begin{array}{l}\text { ubi } 1 \\
\text { promoter or } \\
\text { mpi } \\
\text { promoter }\end{array}$ & $\begin{array}{l}\text { Striped stem } \\
\text { borer }\end{array}$ & $\begin{array}{l}\text { Breitler et al. } \\
\text { (2004) }\end{array}$ \\
\hline 32 & $\begin{array}{l}\text { crylAb, cry } 1 A c, \\
\text { cry } 1 C, \text { cry } 2 A, \\
\text { cry } 9 C\end{array}$ & Indica rice & - & $\begin{array}{l}\text { Yellow stem } \\
\text { borer, Striped } \\
\text { stem borer }\end{array}$ & $\begin{array}{l}\text { Alcantara et al. } \\
\text { (2004) }\end{array}$ \\
\hline 33 & $\begin{array}{l}\text { mpi gene (maize } \\
\text { proteinase } \\
\text { inhibitor) }\end{array}$ & Senia and Ariete & $\begin{array}{l}\text { Maize } \\
\text { ubiquitin } 1 \\
\text { promoter }\end{array}$ & $\begin{array}{l}\text { Striped stem } \\
\text { borer }\end{array}$ & $\begin{array}{l}\text { Vila et al. } \\
\text { (2005) }\end{array}$ \\
\hline 34 & cry $2 A$ & $\begin{array}{l}\text { Minghui } 63 \text { (indica } \\
\text { restorer line) }\end{array}$ & $\begin{array}{l}\text { Maize } \\
\text { ubiquitin } \\
\text { promoter }\end{array}$ & $\begin{array}{l}\text { Yellow stem } \\
\text { borer }\end{array}$ & $\begin{array}{l}\text { Chen et al. } \\
\text { (2005) }\end{array}$ \\
\hline 35 & cry $1 A c$, cry $2 A$ & $\begin{array}{l}\text { Basmati line B-370 } \\
\text { (indica rice) }\end{array}$ & - & $\begin{array}{l}\text { Yellow stem } \\
\text { borer, } \\
\text { leaffolder }\end{array}$ & $\begin{array}{l}\text { Bashir et al. } \\
\text { (2005) }\end{array}$ \\
\hline 36 & cry $1 A c$, cry $2 A$ & $\begin{array}{l}\text { Basmati } 370 \text { (indica } \\
\text { rice) }\end{array}$ & $\begin{array}{l}\text { Ubiquitin } \\
\text { promoter and } \\
\text { CaMV } 35 \mathrm{~S} \\
\text { promoter }\end{array}$ & $\begin{array}{l}\text { Yellow stem } \\
\text { borer }\end{array}$ & $\begin{array}{l}\text { Riaz et al. } \\
(2006)\end{array}$ \\
\hline
\end{tabular}


Table 2 (continued)

\begin{tabular}{|c|c|c|c|c|c|}
\hline S. No. & $\begin{array}{l}\text { Transgene(s) } \\
\text { deployed }\end{array}$ & $\begin{array}{l}\text { Recipient rice variety/ } \\
\text { genotype }\end{array}$ & $\begin{array}{l}\text { Promoter } \\
\text { deployed }\end{array}$ & $\begin{array}{l}\text { Reported } \\
\text { resistant } \\
\text { against }\end{array}$ & Reference(s) \\
\hline 37 & $\begin{array}{l}\text { cry } 1 A b-1 B \\
\text { (translationally } \\
\text { fused gene) and } \\
\text { cry } 1 A / \text { cry } 1 A c \\
\text { (hybrid } B t \text { gene) } \\
\end{array}$ & $\begin{array}{l}\text { Elite } \\
\text { Vietnamese cultivars }\end{array}$ & $\begin{array}{l}\text { Maize } \\
\text { ubiquitin } \\
\text { promoter and } \\
\text { rice actin-1 } \\
\text { promoter } \\
\end{array}$ & $\begin{array}{l}\text { Yellow stem } \\
\text { borer }\end{array}$ & $\begin{array}{l}\text { Ho et al. } \\
\text { (2006) }\end{array}$ \\
\hline 38 & $\begin{array}{l}\text { PINII (potato } \\
\text { proteinase } \\
\text { inhibitor) }\end{array}$ & $\begin{array}{l}\text { Pusa basmati-1 and } \\
\text { Tarori Basmati } \\
\text { (indica rice) and } \\
\text { TNG67 (japonica } \\
\text { rice) }\end{array}$ & $\begin{array}{l}\text { Pin2 } \\
\text { wound- } \\
\text { inducible } \\
\text { promoter }\end{array}$ & $\begin{array}{l}\text { Yellow stem } \\
\text { borer }\end{array}$ & $\begin{array}{l}\text { Bhutani et al } \\
\text { (2006) }\end{array}$ \\
\hline 39 & cry $2 A b$ gene & $\begin{array}{l}\text { Minghui } 63 \text { (indica } \\
\text { restorer } \\
\text { line)/T(1 }(1 \mathrm{Ab})-10\end{array}$ & - & $\begin{array}{l}\text { Yellow stem } \\
\text { borer, } \\
\text { leaffolder }\end{array}$ & $\begin{array}{l}\text { Tang and Lin } \\
\text { (2007) }\end{array}$ \\
\hline 40 & crylAb & $\begin{array}{l}\text { Korean varieties, P-I, } \\
\text { P-II, P-III }\end{array}$ & $\begin{array}{l}\text { Maize } \\
\text { ubiquitin } \\
\text { promoter }\end{array}$ & $\begin{array}{l}\text { Yellow stem } \\
\text { borer }\end{array}$ & $\begin{array}{l}\text { Kim et al. } \\
(2008)\end{array}$ \\
\hline 41 & crylAb gene & $\begin{array}{l}\text { Khazar, Neda, and } \\
\text { Nemat }\end{array}$ & - & $\begin{array}{l}\text { Striped stem } \\
\text { borer }\end{array}$ & $\begin{array}{l}\text { Kiani et al. } \\
\text { (2008) }\end{array}$ \\
\hline 42 & $\begin{array}{l}\text { Ten transgenic } \\
\text { lines (two } \\
\text { cry1Ac lines, } \\
\text { three } \text { cry } 2 A \\
\text { lines, five } \text { cry } 9 C \\
\text { lines) }\end{array}$ & $\begin{array}{l}\text { Minghui } 63 \text { (elite } \\
\text { indica restorer line) }\end{array}$ & - & $\begin{array}{l}\text { Yellow stem } \\
\text { borer, striped } \\
\text { stem borer }\end{array}$ & $\begin{array}{l}\text { Chen et al. } \\
\text { (2008) }\end{array}$ \\
\hline 43 & crylC & $\begin{array}{l}\text { Zhonghua } 11 \text { (Oryza } \\
\text { sativa L. subsp. } \\
\text { japonica)/RJ5 line. }\end{array}$ & $\begin{array}{l}\text { rbcS } \\
\text { promoter }\end{array}$ & $\begin{array}{l}\text { Yellow stem } \\
\text { borer, striped } \\
\text { stem borer, } \\
\text { leaffolder }\end{array}$ & $\begin{array}{l}\text { Ye et al. } \\
\text { (2009) }\end{array}$ \\
\hline 44 & crylIa5 & Oryza sativa & - & $\begin{array}{l}\text { Yellow stem } \\
\text { borer }\end{array}$ & $\begin{array}{l}\text { Moghaieb } \\
(2010)\end{array}$ \\
\hline 45 & $\begin{array}{l}c r y 1 b \text { and } \\
\text { crylA } a \text { fusion } \\
\text { gene }\end{array}$ & Oryza sativa & $\begin{array}{l}\text { PEPC } \\
\text { promoter }\end{array}$ & $\begin{array}{l}\text { Yellow stem } \\
\text { borer }\end{array}$ & $\begin{array}{l}\text { Kumar et al. } \\
\text { (2010) }\end{array}$ \\
\hline 46 & $\begin{array}{l}\text { crylA } b \text { and } \\
\text { Vip3H fusion } \\
\text { gene }\end{array}$ & $\begin{array}{l}\text { G6H1, G6H2, G6H3, } \\
\text { G6H4, G6H5, G6H6 }\end{array}$ & - & $\begin{array}{l}\text { Striped stem } \\
\text { borer, pink } \\
\text { stem borer }\end{array}$ & $\begin{array}{l}\text { Chen et al. } \\
\text { (2010) }\end{array}$ \\
\hline 47 & $\begin{array}{l}\text { crylAb, crylAc } \\
\text { fusion gene }\end{array}$ & Bt-SY63 & - & $\begin{array}{l}\text { Striped stem } \\
\text { borer }\end{array}$ & $\begin{array}{l}\text { Zhang et al. } \\
\text { (2011) }\end{array}$ \\
\hline 48 & $\begin{array}{l}\text { crylAc, CpTI } \\
\text { genes }\end{array}$ & Bt-KF6 & - & $\begin{array}{l}\text { Striped stem } \\
\text { borer }\end{array}$ & $\begin{array}{l}\text { Zhang et al. } \\
\text { (2011) }\end{array}$ \\
\hline 49 & crylAb & Bt-DL & - & $\begin{array}{l}\text { Striped stem } \\
\text { borer }\end{array}$ & $\begin{array}{l}\text { Zhang et al. } \\
\text { (2011) }\end{array}$ \\
\hline
\end{tabular}


Table 2 (continued)

\begin{tabular}{|c|c|c|c|c|c|}
\hline S. No. & $\begin{array}{l}\text { Transgene(s) } \\
\text { deployed }\end{array}$ & $\begin{array}{l}\text { Recipient rice variety/ } \\
\text { genotype }\end{array}$ & $\begin{array}{l}\text { Promoter } \\
\text { deployed }\end{array}$ & $\begin{array}{l}\text { Reported } \\
\text { resistant } \\
\text { against }\end{array}$ & Reference(s) \\
\hline 50 & $\begin{array}{l}\text { cry } 1 A b, \text { cry } 1 A c, \\
\text { cry } 1 C, \text { cry } 2 A\end{array}$ & $\begin{array}{l}\text { Minghui } 63 \text { (elite } \\
\text { indica restorer line) }\end{array}$ & $\begin{array}{l}\text { Maize } \\
\text { ubiquitin } \\
\text { promoter }\end{array}$ & $\begin{array}{l}\text { Yellow stem } \\
\text { borer, striped } \\
\text { stem borer, } \\
\text { leaffolder }\end{array}$ & $\begin{array}{l}\text { Yang et al. } \\
\text { (2011) }\end{array}$ \\
\hline 51 & $\begin{array}{l}\text { CrylAc, } \\
\text { crylI-like gene }\end{array}$ & Rice & pGreen & $\begin{array}{l}\text { Striped stem } \\
\text { borer, } \\
\text { leaffolder }\end{array}$ & $\begin{array}{l}\text { Yang et al. } \\
\text { (2014) }\end{array}$ \\
\hline 52 & $c r y l A b$ gene & Mfb-MH86 & $\begin{array}{l}\text { Ubiquitin } \\
\text { promoter }\end{array}$ & $\begin{array}{l}\text { Striped stem } \\
\text { borer and } \\
\text { other } \\
\text { lepidopteran } \\
\text { pests }\end{array}$ & $\begin{array}{l}\text { Wang et al. } \\
\text { (2014) }\end{array}$ \\
\hline 53 & $\begin{array}{l}\text { mpi-pci fusion } \\
\text { gene }\end{array}$ & Ariete & $\begin{array}{l}\text { mpi } \\
\text { promoter }\end{array}$ & $\begin{array}{l}\text { Striped stem } \\
\text { borer }\end{array}$ & $\begin{array}{l}\text { Quilis et al. } \\
\text { (2014) }\end{array}$ \\
\hline 54 & $D s-B t$ & $\begin{array}{l}\text { Zhejing-22, } \\
\text { Kongyu-131 }\end{array}$ & - & $\begin{array}{l}\text { Striped stem } \\
\text { borer }\end{array}$ & $\begin{array}{l}\text { Gao et al. } \\
(2014)\end{array}$ \\
\hline 55 & $\begin{array}{l}\text { crylAc, cryllg, } \\
\text { G10 (EPSPS } \\
\text { gene) }\end{array}$ & Xiushui 134 & $\begin{array}{l}\text { Maize } \\
\text { ubiquitin } \\
\text { promoter } \\
\text { (pUBi)/ } \\
\text { modified } \\
\text { cauliflower } \\
\text { 35S } \\
\text { promoter }\end{array}$ & $\begin{array}{l}\text { Striped stem } \\
\text { borer, } \\
\text { leaffolder, } \\
\text { and } \\
\text { glyphosate }\end{array}$ & Zhao (2015) \\
\hline \multicolumn{6}{|c|}{ Sucking pests } \\
\hline 56 & $\begin{array}{l}\text { GNA (Galanthus } \\
\text { nivalis } \\
\text { agglutinin) }\end{array}$ & $?$ & $\begin{array}{l}\text { Phloem- } \\
\text { specific } \\
\text { rice-sucrose- } \\
\text { synthase }\end{array}$ & $\mathrm{BPH}$ & $\begin{array}{l}\text { Rao et al. } \\
\text { (1998) }\end{array}$ \\
\hline 57 & GNA & ASD16/M12 & $\begin{array}{l}\text { Rice sucrose } \\
\text { synthase/ } \\
\text { maize } \\
\text { ubiquitin }\end{array}$ & $\begin{array}{l}\text { BPH and } \\
\text { GLH }\end{array}$ & $\begin{array}{l}\text { Foissac et al. } \\
(2000)\end{array}$ \\
\hline 58 & GNA & $?$ & $?$ & SBPH & $\begin{array}{l}\text { Wu et al. } \\
(2002)\end{array}$ \\
\hline 59 & GNA & $\begin{array}{l}\text { Chaitanya and } \\
\text { Phalguna, indica } \\
\text { cultivars }\end{array}$ & $\begin{array}{l}\text { Phloem- } \\
\text { specific } \\
\text { rice-sucrose- } \\
\text { synthase }\end{array}$ & $\begin{array}{l}\mathrm{BPH}, \mathrm{GLH}, \\
\text { and } \mathrm{WBPH}\end{array}$ & $\begin{array}{l}\text { Nagadhara } \\
\text { et al. (2003, } \\
\text { 2004) }\end{array}$ \\
\hline 60 & GNA & & & $\begin{array}{l}\mathrm{BPH}, \mathrm{GLH}, \\
\text { and } \mathrm{WBPH}\end{array}$ & $\begin{array}{l}\text { Ramesh et al. } \\
(2004 a, b)\end{array}$ \\
\hline 61 & GNA & $\begin{array}{l}\text { Zhuxian B, an indica } \\
\text { rice }\end{array}$ & & $\mathrm{BPH}$ & Li et al. (2005) \\
\hline
\end{tabular}


Table 2 (continued)

\begin{tabular}{|c|c|c|c|c|c|}
\hline S. No. & $\begin{array}{l}\text { Transgene(s) } \\
\text { deployed }\end{array}$ & $\begin{array}{l}\text { Recipient rice variety/ } \\
\text { genotype }\end{array}$ & $\begin{array}{l}\text { Promoter } \\
\text { deployed }\end{array}$ & $\begin{array}{l}\text { Reported } \\
\text { resistant } \\
\text { against }\end{array}$ & Reference(s) \\
\hline 62 & $\begin{array}{l}\text { ASAL (Allium } \\
\text { sativum } \\
\text { agglutinin) }\end{array}$ & IR64 & CaMV35S & $\begin{array}{l}\text { BPH and } \\
\text { GLH }\end{array}$ & $\begin{array}{l}\text { Saha et al. } \\
(2006)\end{array}$ \\
\hline 63 & $A S A L$ & $\begin{array}{l}\text { Chaitanya and } \\
\text { BPT5204, indica } \\
\text { cultivars }\end{array}$ & CaMV35S & $\begin{array}{l}\mathrm{BPH}, \mathrm{GLH}, \\
\text { and WBPH }\end{array}$ & $\begin{array}{l}\text { Yarasi et al. } \\
\text { (2008) }\end{array}$ \\
\hline 64 & $A S A L$ & IR64 & CaMV35S & $\begin{array}{l}\text { BPH and } \\
\text { GLH }\end{array}$ & $\begin{array}{l}\text { Sengupta et al. } \\
\text { (2010) }\end{array}$ \\
\hline 65 & $\begin{array}{l}\text { DB1/G95A- } \\
\text { mALS } \\
\text { (Dioscoria } \\
\text { batata } \text { tuber } \\
\text { lectin) }\end{array}$ & Tachisugata & $\begin{array}{l}\text { Phloem- } \\
\text { specific } \\
\text { rice-sucrose- } \\
\text { synthase }\end{array}$ & $\mathrm{BPH}$ & $\begin{array}{l}\text { Yoshimura } \\
\text { et al. (2012) }\end{array}$ \\
\hline 66 & $A S A L$ & $?$ & $\begin{array}{l}\text { Phloem- } \\
\text { specific } \\
\text { rice-sucrose- } \\
\text { synthase }\end{array}$ & $\mathrm{BPH}$ & $\begin{array}{l}\text { Chandrasekhar } \\
\text { et al. (2014) }\end{array}$ \\
\hline 67 & $\begin{array}{l}\text { Loop } \\
\text { replacements } \\
\text { with gut-binding } \\
\text { peptides in } \\
\text { CrylAb domain } \\
\text { II }\end{array}$ & In vitro assay & - & $\mathrm{BPH}$ & $\begin{array}{l}\text { Shao et al. } \\
\text { (2016) }\end{array}$ \\
\hline 68 & $\begin{array}{l}\text { Cry64Ba and } \\
C r y 64 \mathrm{Ca}\end{array}$ & report & & $\begin{array}{l}\text { Effective } \\
\text { against } \\
\text { sap-sucking } \\
\text { insects }\end{array}$ & $\begin{array}{l}\text { Liu et al. } \\
\text { (2018) }\end{array}$ \\
\hline
\end{tabular}

several such transgenic rice lines have been deregulated by the respective regulatory authorities of these countries due to various policy-related issues.

Genetic engineering for the control of planthopper and leafhopper pests of rice has begun with the use of plant-derived lectin genes. The snowdrop lectin gene, Galanthus nivalis agglutinin (GNA), has been transferred to several rice varieties and has been shown to provide partial to complete resistance to planthoppers and leafhoppers. Partial resistance to leafhoppers and planthoppers was demonstrated by rice transformation with a lectin gene from garlic (Allium sativum leaf agglutinin gene, ASAL; Saha et al. 2006). Bala et al. (2013) reported that $A S A L$ interacts with NADH quinone oxidoreductase (NQO), a key player in the electron transport chain, and results in toxicity and increased mortality of BPH in transgenic rice lines. This study also demonstrated that, among all the transgenes available for control of sucking pests, $A S A L$ holds significant promise, particularly against BPH. Yoshimura et al. (2012) developed transgenic rice possessing lectin1 gene from Dioscorea batatas under the control of a phloem-specific promoter (i.e., promoter of sucrose synthase- 1 gene) that showed a $30 \%$ decrease in the survival rate of BPH. Even 
though, in general, it is known that Cry proteins are ineffective against sucking pests, through loop replacements with gut-binding peptides in CrylAB domain II, enhanced toxicity against BPH has been demonstrated (Shao et al. 2016). Liu et al. (2018) have shown the effectivity of Cry64Ba and Cry64Ca, two ETX/MTX2-type $B t$ proteins, against hemipteran pests. Boddupally et al. (2018) recently demonstrated that the expression of hybrid fusion protein (Cry1Ac::ASAL) in transgenic rice plants imparted resistance against multiple insect pests: $\mathrm{BPH}$, stem borer, and leaffolder. The list of transgenes deployed for the control of sucking pests such as BPH is summarized in Table 2.

\section{Insect-Plant Interactions at the Genomic Level}

\subsection{Planthopper Genomes}

The genome of BPH and its endosymbionts have been sequenced (Xue et al. 2014). It is a large genome $(1141 \mathrm{Mb})$ with 27,571 protein-coding genes, of which 16,330 are specific to this species. In comparison, the WBPH genome is relatively smaller $(720 \mathrm{Mb}$ ) with 21,254 protein-coding genes (L Wang et al. 2017a), while the SBPH genome size is $541 \mathrm{Mb}$ with 17,736 protein-coding genes (Zhu et al. 2017c). Mitochondrial (mt) genomes of these three planthopper species have also been sequenced (Zhang et al. 2013, 2014). These studies are now providing insights into the genetic plasticity of this group, possible causes of rapid evolution of virulent biotypes, and resistance against a wide range of synthetic insecticides. In addition, the role of endosymbionts such as yeast-like symbiont (YLS) and Wolbachia spp. in enhancing insect fitness is being studied. Additional genetic markers are being developed for studying population genetics, individual differences, and the phylogeography of planthoppers. Several key genes of the insects have been identified, which can be targeted for RNAi-based genetic tools of pest management. Transcriptomics of the salivary gland has revealed more than 350 secretory proteins, of which several, such as NISEF1 (W Ye et al. 2017a), act as effectors modulating plant defense response. Likewise, muscin-like protein of the salivary gland secretion of BPH (Huang et al. 2017; Shangguan et al. 2018) and WBPH (Miao et al. 2018) is likely to be an effector. Such genes can be suitable targets for their control using an RNAi-based approach described above. A high number of cytochrome P450 genes and their functional diversification are attributed to drive the evolution of insecticide resistance and virulence against host-plant resistance (Peng et al. 2017; Zimmer et al. 2018). In spite of efforts to map virulence loci onto the BPH genome (Jing et al. 2014; Kobayashi et al. 2014), no aviR gene has yet been cloned and characterized. Although mitochondrial markers based on mt genes COI and ND4 have been screened for population differentiation, the results have not been encouraging over large populations across countries. Further, Zhang et al. (2013) suggest that markers based on the control region of the mt genome might provide more reliable markers for studying population genetics and the phylogeography of planthoppers. 


\subsection{Rice-Planthopper Interactions}

Using both candidate gene cloning and a characterization-based approach and functional genomics-based omics approaches, attempts are being made to understand planthopper and rice interactions. Based on initial information on the nature of $\mathrm{R}$ genes as being members of the NBS-LRR class or receptor kinase class, the rice resistance mechanism against $\mathrm{BPH}$ is, rather hurriedly, aligned to rice resistance against pathogens under two-tier immunity involving pattern-triggered immunity (PTI) and effector-triggered immunity (ETI) and the involvement of both JA- and SA-mediated pathways (Jing et al. 2017). Even the cloned genes are assigned to PTI (Bph3, Bph15) or ETI (Bph14, Bph1/10/18) tiers. However, what is not accounted for is the lack of documented evidence of hypersensitive reaction (HR) and systemic acquired resistance (SAR), which are hallmarks of plant response to biotrophic pathogens. Further, resistance in rice against planthoppers is not at the immune level but with moderate antibiosis coupled with antifeeding and antixenosis components. It is generally understood that SA- and JA-mediated plant defenses act reciprocally antagonistic to each other with adaptive significance (Thaler et al. 2012). Such antagonism has not been convincingly illustrated in the case of planthopper resistance in rice. Thus, greater understanding of planthopper-rice interactions is needed.

\subsection{Rice-Gall Midge Interactions}

Although genome sequence data for ARGM are yet to be published (Nair et al. unpublished), the mitogenome has been sequenced (Atray et al. 2015) and the microbiome analyzed in different stages of the life cycle of the insect (Ojha et al. 2017). Based on identification and functional analysis of candidate genes, global gene expression profiles and differential gene expressions detected through SSH cDNA libraries, microarray studies, and the pyrosequencing approach in both the plants and the insect rice-gall midge interactions have been fairly well studied. In essence, with results from these studies indicating strategies used by both the pest and the host to defeat each other, defense ploys can be termed as a battle for survival (Bentur et al. 2016; Sinha et al. 2017).

During the infestation process and subsequent feeding on the host, the larvae inject substance(s) into the host. As in the case of pathogenic bacteria and fungi, these products could be determinants (effectors) of the avirulence/virulence phenomenon. Extending this idea further, the genes that encode these molecules could be determinants of gall midge biotypes. Further, the genes that encode such molecules could be those that encode secreted salivary gland proteins (SSGPs). Therefore, characterizing genes that encode SSGPs could provide a handle to study this interaction and also gain valuable insight into the process of infestation of rice by this pest. The expression patterns of some of these SSGPs in larvae interacting with a susceptible host ( $\mathrm{SH}$; compatible interaction) or resistant host (RH; incompatible interaction) indicated that some of the SSGPs such as gamma subunit of 
oligosaccharyl transferase (OoOST) and nucleoside diphosphate kinase (OoNDPK) overexpress when interacting with SH compared with those in maggots when feeding on RH (Sinha et al. 2011a, 2012a). Furthermore, NDPK protein has been demonstrated to influence the host physiology. In contrast, two genes, OoprotI and OoprotII, homologous to serine proteases, and OoDADI (defender against death) overexpress in midgut of the maggots feeding on RH when compared with those feeding on SH (Sinha et al. 2011b, 2015). Although the former interactions represent effector-induced susceptibility, the latter set forms neutralizers attempting to overcome plant-secreted defensive toxins. Earlier studies also brought out similarities in rice defense expression against gall midge with those seen against plant pathogens (Rawat et al. 2010, 2013), complete with HR and SAR. Subsequent analysis of SSH-generated cDNA libraries and microarray data brought out differences in the defense pathways underlying HR+-type and HR--type resistance (Rawat et al. 2012b), among the two HR-type resistances conferred by Gml and Gm8 genes (Divya et al. 2016, 2018b), and also the diversity in susceptibility pathways in rice genotypes with ineffective R-genes against virulent biotypes (Rawat et al. 2012a). Generally, in the three gall midge-susceptible rice varieties studied, the insectchallenged plants tend to step up metabolism and transport of nutrients to their feeding site and have suppressed defense responses. However, one of the rice varieties mounted an elevated defense response during early hours of infestation, only to be overpowered later, eventually resulting in host-plant susceptibility.

Pyrosequencing-based transcriptome analysis of ARGM revealed a differential response of the midge depending on whether it is in a compatible or incompatible interaction with its host (Sinha et al. 2012b). A recent study with sequencing of $16 \mathrm{~S}$ rRNA bacterial gene (V3-V4 region) revealed differences in the microflora of the gall midge-rice maggots feeding on susceptible or resistant rice hosts. Results revealed that Wolbachia was the predominant bacterium in pupae and adults while Pseudomonas was predominant in maggots. Further, it was observed that members of proteobacteria were predominant across all the samples. There was high species diversity in maggots isolated from susceptible rice and a high representation of unclassified bacteria in maggots isolated from resistant rice. A first step in this direction is a report that highlights variation in the microbiome of the rice gall midge, based on the host phenotype from which it was isolated, and results suggest that these variations could have an important role in the host's susceptibility/resistance (Ojha et al. 2017).

The availability of the complete sequence of the gall midge mt genome and subsequent sequence analysis revealed the presence of two tandem repeat elements in the noncoding regions of the mt genome. Further, sequencing of the iterated regions demonstrated that the iterations of the repeat elements could not only differentiate different gall midge biotypes present in India but also were able to genetically separate the ARGM from its counterpart, the African rice gall midge (Atray et al. 2015). Thus, this study identified a reliable tool to monitor changes in the insect populations so as to have an "early warning system" in place. Janique et al. (2017) reported that two noncoding repeat motifs observed in the mitogenome of ARGM in India were absent in Thai populations and these were replaced by an 89-bp noncoding sequence. 


\section{Conclusions and Perspectives}

In terms of an evolutionary perspective, survival of neither the host nor the herbivore has ever been under threat. Understandably, however, over the past couple of millennia when half of the human population started depending on this one cereal as its staple food, conflict of interest erupted between these insects and humans. All feasible efforts were made to protect the crop from possible damage by insects during the early phase of domestication and cultivation of the rice crop. With the advent of modern scientific methods of crop husbandry, crop improvement, and synthetic chemicals, insect pests became targets of a frontal attack by humans. With quick development of resistance against a range of synthetic insecticides, insect pests proved their evolutionary superiority, compelling humans to concede defeat and conclude that pest management was the best solution for sustainable productivity rather than pest eradication or control. Rice insect pest management has traversed the same course as that in other crops such as cotton.

Insect pest management is complex and fraught with many variables. From the foregoing account, it is quite clear that we are just beginning to understand and make inroads into the complex interactions between the pest and its host, rice. It is also evident that, although productivity loss due to these insects alone runs into several million US dollars, insects are rapidly overcoming any management strategy that we are able to deploy, whether it is resistance genes or the development of new pesticides. What this review hopes to highlight primarily is that as a central concept we need to know how the rice plant interacts with its several insect enemies from an evolutionary point of view. Against YSB, no high resistance is expressed, probably because it is a " $\mathrm{k}$ " strategist and monophagous insect that does not kill the host. Against gall midge with an intermediate population strategy displaying buck and boost cycles, the host plant has a diverse array of immune-level R-genes that are constantly evolving along with the virulence in the pest populations. In stark contrast, the rice plant has stockpiled multiple major and minor R-genes against planthoppers, which are typical "r" strategists. Second, the molecular tools now available have provided novel products for deployment to alleviate pest-induced yield losses. Notable among these are gene-pyramided elite cultivars, derived from markerassisted selection, to manage multiple pests and their strains/biotypes (Divya et al. 2018c). Also present is the array of transgenic rice lines with potent genes against all the guilds of insect pests. It is unfortunate that these products are not yet available for commercial use. Molecular approaches have also broadened our knowledge and identified unexplored facets for possible use in pest management. Finally, this flush in information has reiterated the evolutionary advantage of insect genome, mitogenome, and metagenome in facing any future challenges. A recent report on quick field selection for dsRNA resistance in western corn rootworm (Khajuria et al. 2018) exemplifies this. As summarized, representatives of each insect guild have evolved their own strategy to overcome plant resistance. Considering that, in the coming years, we are likely to be under pressure to grow more in less area, it is therefore imperative that we cut the losses in productivity due to insect pests. 
We have made rapid strides in the past couple of decades toward this goal with emerging new tools and strategies. What is also clear is that the solution to the insect problem is unlikely to come from one area of study but from an amalgamation of information obtained from several different studies that can provide durable, effective, and targeted resistance to insect pests of rice. The caveat is that this is unlikely to be a one-time effort but must be a continuing one.

\section{References}

Abhilash Kumar V, Balachiranjeevi C, Naik BS et al (2017) Marker-assisted pyramiding of bacterial blight and gall midge resistance genes into RPHR-1005, the restorer line of the popular rice hybrid DRRH-3. Mol Breed 37:86. https://doi.org/10.1007/s11032-017-0687-8

Agarwal S, Mohan M, Mangrauthia SK (2012) RNAi: machinery and role in pest and disease management. In: Venkateshwarlu B, Shankar AK, Shankar C, Maheshwari M (eds) Crop stress and its management: perspectives and strategies. Springer, New York, pp 447-469

Aglawe SB, Barbadikar KM, Mangrauthia SK, Madhav MS (2018) New breeding technique "genome editing" for crop improvement: applications, potentials and challenges. 3 Biotech $8(8): 336$

Alam MF, Datta K, Abrigo E et al (1998) Production of transgenic deep water indica rice plants expressing a synthetic Bacillus thuringiensis crylAb gene with enhanced resistance to yellow stem borer. Plant Sci 135(1):25-30

Alam MF, Abrigo E, Datta K et al (1999) Transgenic insect resistance maintainer line (IR68899B) for improvement of hybrid rice. Plant Cell Rep 18:572-575

Alcantara EP, Aguda RM, Curtiss A et al (2004) Bacillus thuringiensis delta endotoxin binding to brush border membrane vesicles of rice stem borers. Arch Insect Biochem Physiol 55(4):169-177. https://doi.org/10.1002/arch.10128

Amudhan S, Prasad Rao U, Bentur JS (1999) Total phenol profile in some rice varieties in relation to infestation by Asian rice gall midge Orseolia oryzae (Wood-Mason). Curr Sci 76:1577-1580

Andrews RW, Faust R, Wabiko MH et al (1987) The biotechnology of Bacillus thuringiensis. Crit Rev Biotechnol 6:163-232. https://doi.org/10.3109/07388558709113596

Arora L, Narula A (2017) Gene editing and crop improvement using CRISPR-Cas9 system. Front Plant Sci 8:1932. https://doi.org/10.3389/fpls.2017.01932

Atray I, Bentur JS, Nair S (2015) The Asian rice gall midge (Orseolia oryzae) mitogenome has evolved novel gene boundaries and tandem repeats that distinguish its biotypes. PLoS One 10(7):e0134625. https://doi.org/10.1371/journal.pone.0134625

Bala A, Roy A, Behura N, Hess D, Das S (2013) Insight to the mode of action of Allium sativum leaf agglutinin (ASAL) expressing in T3 rice lines on brown planthopper. Am J Plant Sci 4:400-407

Balachandran S, Chandel G, Alam M et al (2002) Improving hybrid rice through anther culture and transgenic approaches. In: 4th International Symposium on Hybrid Rice. Hanoi, Vietnam. IRRI, Los Baños, pp 105-118

Bally J, Fishilevich E, Bowling AJ, Pence HE, Narva KE, Waterhouse PM (2018) Improved insectproofing: expressing double-stranded RNA in chloroplasts. Pest Manag Sci 74:1751-1758

Bashir K, Husnain T, Fatima T, Riaz N, Makhdoom R, Riazuddin S (2005) Novel indica basmati line (B-370) expressing two unrelated genes of Bacillus thuringiensis is highly resistant to two lepidopteran insects in the field. Crop Prot 24:870-879

Baum JA, Bogaert T, Clinton W et al (2007) Control of coleopteran insect pests through RNA interference. Nat Biotechnol 25(11):1322-1326 
Bentur JS (2007) Host-plant resistance to insects as a core of rice IPM. In: Aggarwal PK, Ladha JK, Singh RK, Devkumar C, Hardy B (eds) Science, technology, and trade for peace and prosperity. Proceedings of the 26th International Rice Research Conference, New Delhi, India, 9-12 October 2006. International Rice Research Institute, Indian Council of Agricultural Research, and National Academy of Agricultural Sciences, Los Baños, New Delhi, pp 419-435 Bentur JS (2010) Insect pests of rice in India and their management. In: Reddy DV, Rao NP, Rao KV (eds) Pests and pathogens: management strategies. BS Publications, Hyderabad, pp 1-42

Bentur JS, Viratkamath BC (2008) Rice planthoppers strike back. Curr Sci 95:441-442

Bentur JS, Pasalu IC, Sarma NP, Prasad Rao U, Mishra B (2003) Gall midge resistance in rice. DRR technical bulletin \#1. Directorate of Rice Research, Hyderabad. $20 \mathrm{p}$

Bentur JS, Padmakumari AP, Jhansilakshmi V et al (2011) Insect resistance in rice. DRR technical bulletin \#51. Directorate of Rice Research, Hyderabad. $86 \mathrm{p}$

Bentur JS, Rawat N, Divya D, Sinha DK, Agarrwal R, Atray I, Nair S (2016) Rice-gall midge interactions: battle for survival. J Insect Physiol 84:40-49. dx.doi.org. https://doi.org/10.1016/j. jinsphys.2015.09.008

Bhutani S, Kumar R, Chauhan R et al (2006) Development of transgenic indica rice plants containing potato proteinase inhibitor 2 gene with improved defense against yellow stem borer. Physiol Mol Biol Plants 12(1):43-52

Bi HL, Xu J, Tan AJ, Huang YP (2016) CRISPR/Cas9-mediated targeted gene mutagenesis in Spodoptera litura. Insect Sci 23:469-477

Boddupally D, Tamirisa S, Gundra SR, Vudem DR, Rao KV (2018) Expression of hybrid fusion protein (Cry1Ac::ASAL) in transgenic rice plants imparts resistance against multiple insect pests. Sci Rep 8:8458. https://doi.org/10.1038/s41598-018-26881-9

Breitler JC, Vassal JM, Catala MDM et al (2004) Bt rice harbouring cry genes controlled by a constitutive or wound-inducible promoter: protection and transgene expression under Mediterranean field conditions. Plant Biotechnol J 2:417-430

Bunsha D (2006) Crops on trial. Frontline 23(23) http://www.hinduonnet.com/fline/fl2323/stories/20061201003603000.htm. Accessed 15 Jan 2008

Cha YS, Ji H, Yun DW et al (2008) Fine mapping of the rice Bphl gene, which confers resistance to the brown planthopper (Nilaparvata lugens Stal), and development of STS markers for marker-assisted selection. Mol Cell 26:146-151

Chandrasekhar K, Reddy MG, Singh J, Vani K, Vijayalakshmi M, Kaul T, Reddy MK (2014) Development of transgenic rice harbouring mutated rice 5-Enolpyruvylshikimate 3-Phosphate Synthase (Os-mEPSPS) and Allium sativum leaf agglutinin (ASAL) genes conferring tolerance to herbicides and sap-sucking insects. Plant Mol Biol Report 32(6):1146. https://doi. org/10.1007/s11105-014-0715-3

Chen H, Tang W, Xu C et al (2005) Transgenic indica rice plants harboring a synthetic cry2A gene of Bacillus thuringiensis exhibit enhanced resistance against lepidopteran rice pests. Theor Appl Genet 111:1330-1337

Chen M, Zhao JZ, Ye GY, Fu Q, Shelton AM (2006) Impact of insect-resistant transgenic rice on target insect pests and non-target arthropods in China. Insect Sci 13:409-420

Chen H, Zhang G, Zhang Q, Lin Y (2008) Effect of transgenic Bacillus thuringiensis rice lines on mortality and feeding behavior of rice stem borers (Lepidoptera: Crambidae). J Econ Entomol 101:182-189. https://doi.org/10.1093/jee/101.1.182

Chen Y, Tian J, Shen Z et al (2010) Transgenic rice plants expressing a fused protein of CrylAb/ Vip $3 \mathrm{H}$ have resistance to rice stem borers under laboratory and field conditions. J Econ Entomol 103(4):1444-1453. https://doi.org/10.1603/EC10014

Chen M, Shelton A, Ye G (2011) Insect-resistant genetically modified rice in China: from research to commercialization. Annu Rev Entomol 56:81-101

Cheng X, Sardana R, Kaplan H et al (1998) Agrobacterium-transformed rice plants expressing synthetic $\operatorname{cry} 1 A(\mathrm{~b})$ and $\operatorname{cry} 1 A(\mathrm{c})$ genes are highly toxic to striped stem borer and yellow stem borer. Proc Natl Acad Sci U S A 95(6):2767-2772. https://doi.org/10.1073/pnas.95.6.2767 
Cohen MB, Romena AM, Gould F (2000) Dispersal by larvae of the stem borers Scirpophaga incertulas (Lepidoptera: Pyralidae) and Chilo suppressalis (Lepidoptera: Crambidae) in plots of transplanted rice. Environ Entomol 29:958-971. https://doi.org/10.1603/0046-225x-29.5.958

Courtier-Orgogozo V, Morizot B, Boëte C (2017) Agricultural pest control with CRISPR-based gene drive: time for public debate. Should we use gene drive for pest control? EMBO Rep 18:878-880

Datta K, Vasquez A, Tu J et al (1998) Constitutive and tissue specific differential expression of $c r y l A b$ gene in transgenic rice plants conferring resistance of rice insect pest. Theor Appl Genet 97:20-30

Datta K, Baisakh N, Thet K et al (2002) Pyramiding transgenes for multiple resistance in rice against bacterial blight, yellow stem borer and sheath blight. Theor Appl Genet 106:1-8

Deutsch CA, Tewksbury JJ, Tigchelaar M et al (2018) Increase in crop losses to insect pests in a warming climate. Science 361:916-919

Divya D, Himabindu K, Nair S, Bentur JS (2015) Cloning of a gene encoding LRR protein and its validation as candidate gall midge resistance gene, Gm4, in rice. Euphytica 203:185-195

Divya D, Tunginba Singh Y, Nair S, Bentur JS (2016) Analysis of SSH library of rice variety Aganni reveals candidate gall midge resistance genes. Funct Integr Genom 16:153-169

Divya D, Nair S, Bentur JS (2018a) Expression profiles of key genes involved in rice gall midge interactions reveal diversity in resistance pathways. Curr Sci 115:74-82

Divya D, Sahu N, Nair S, Bentur JS (2018b) Map-based cloning and validation of a gall midge resistance gene, $G m 8$, encoding a proline-rich protein in the rice variety Aganni. Mol Biol Rep 45:2075. https://doi.org/10.1007/s11033-018-4364-8

Divya D, Ratna Madhavi K, Dass MA et al (2018c) Expression profile of defense genes in rice lines pyramided with resistance genes against bacterial blight, fungal blast and insect gall midge. Rice 11:40

Dong XT, Liao H, Zhu GH et al (2017) CRISPR/Cas9 mediated PBP1 and PBP3 mutagenesis induced significant reduction in electrophysiological response to sex pheromones in male Chilo suppressalis. Insect Sci 26:388. https://doi.org/10.1111/1744-7917.12544

Du B, Zhang W, Liu B et al (2009) Identification and characterization of Bph14, a gene conferring resistance to brown planthopper in rice. Proc Natl Acad Sci U S A 106:22163-22168

Du B, Chen R, He J (2020) Current understanding of the genomic, genetic, and molecular control of insect resistance in rice. Mol Breed 40:24. https://doi.org/10.1007/s11032-020-1103-3

Duan X, Li X, Xue Q et al (1996) Transgenic rice plants harboring an introduced potato proteinase inhibitor II gene are insect resistant. Nat Biotechnol 14:494-498. https://doi.org/10.1038/ nbt0496-494

Foissac X, Nguyen TL, Christou P, Gatehouse AMR, Gatehouse JA (2000) Resistance to green leafhopper (Nephotettix virescens) and brown planthopper (Nilaparvata lugens) in transgenic rice expressing snowdrop lectin (Galanthus nivalis agglutinin; GNA). J Insect Physiol 46:573-583

Fujimoto H, Itoh K, Yamamoto M, Kyozuka J, Shimamoto K (1993) Insect-resistant rice generated by introduction of a modified endotoxin gene of Bacillus thuringiensis. Biotechnology 11:1151-1155

Fujita D, Doi K, Yoshimura A, Yasui H (2004) Introgression of a resistance gene for green rice leafhopper from Oryza nivara into cultivated rice, Oryza sativa L. Rice Genet News1 21:64-66

Fujita D, Doi K, Yoshimura A, Yasui H (2006) Molecular mapping of a novel gene, Grh5, conferring resistance to green rice leafhopper (Nephotettix cincticeps Uhler) in rice, Oryza sativa L. Theor Appl Genet 113:567-573

Fujita D, Doi K, Yoshimura A, Yasui H (2010) A major QTL for resistance to green rice leafhopper (Nephotettix cincticeps Uhler) derived from African rice (Oryza glaberrima Steud.). Breed Sci 60:336-341

Fujita D, Kohli A, Horgan FG (2013) Rice resistance to planthoppers and leafhoppers. Crit Rev Plant Sci 32:162-191 
Fukuta T, Tamura K, Hirae M, Oya S (1998) Genetic analysis of resistance to green rice leafhopper (Nephotettix cincticeps (Uhler)) in rice parental line, Norin-PL6, using RFLP markers. Breed Sci 48:243-249

Gao X, Zhou J, Li J et al (2014) Efficient generation of marker-free transgenic rice plants using an improved transposon-mediated transgene reintegration strategy. Plant Physiol 167:11-24. https://doi.org/10.1104/pp.114.246173

Gatehouse JA (2008) Biotechnological prospects for engineering insect-resistant plants. Plant Physiol 146:881-887

Ghareyazie B, Alinia F, Menguito CA et al (1997) Enhanced resistance to two stem borers in an aromatic rice containing a synthetic $C R Y 1 A(B)$ gene. Mol Breed 3:401-404

Gosal SS, Gill R, Sindhu AS et al (2000) Transgenic basmati rice carrying genes for stem borer and bacterial leaf blight resistance. In: Proceedings International Rice Research Conference. IRRI, Los Baños, pp 353-360

Gosal SS, Gill R, Sindhu AS et al (2003) Introducing the crylAc gene into basmati rice and transmitting transgenes to R3 progeny. In: Proceedings International Rice Research Conference. IRRI, Los Baños, pp 558-560

Harini AS, Lakshmi SS, Kumar SS, Sivaramakrishnan S, Kadirvel P (2010) Validation and finemapping of genetic locus associated with resistance to brown planthopper [Nilaparvata lugens (Stål.)] in rice (Oryza sativa L.). Asian J Biol Sci 5:32-37

He K, Xiao H, Sun Y, Ding S, Situ G, Li F (2018) Transgenic microRNA-14 rice shows high resistance to rice stem borer. Plant Biotechnol J 17:461. https://doi.org/10.1111/pbi.12990

Heinrichs EA (1994) Biology and management of rice insects. Wiley Eastern Limited and New Age International Limited, New Delhi. $779 \mathrm{p}$

Heinrichs EA, Medrano FG, Rapusas HR (1985) Genetic evaluation for insect resistance in rice. International Rice Research Institute, Los Baños. 352 p

Heong KL, Hardy B (eds) (2010) Planthoppers: new threats to the sustainability of intensive rice production systems in Asia. International Rice Research Institute, Los Baños. 460 p

Herrnstadt C, Soares GG, Wilcox ER et al (1986) A new strain of Bacillus thuringiensis with activity against coleopteran insects. Nat Biotechnol 4:305-308

High SM, Cohen MB, Shu QY, Altosaar I (2004) Achieving successful deployment of Bt rice. Trends Plant Sci 9:286-292

Himabindu K, Suneetha K, Sama VSAK, Bentur JS (2010) A new rice gall midge resistance gene in the breeding line CR57-MR1523, mapping with flanking markers and development of NILs. Euphytica 174:179-187

Hirabayashi H, Ideta O, Sato H et al (2004) Identification of a resistance gene to brown planthopper derived from Oryza minuta in rice. Breed Res 6(Suppl 1):285

Ho NH, Baisakh N, Oliva N et al (2006) Translational fusion hybrid Bt genes confer resistance against yellow stem borer in transgenic elite Vietnamese rice cultivars. Crop Sci 46:781-789

Horgan FG, Ramal AF, Bentur JS et al (2016) Virulence of brown planthopper (Nilaparvata lugens) populations from South and South East Asia against resistant rice varieties. Crop Prot 78:222-231

Hou LY, Ping YU, Qun XU et al (2011) Genetic analysis and preliminary mapping of two recessive resistance genes to brown planthopper, Nilaparvata lugens Stål in rice. Rice Sci 18:238-242

Huang J, Wei Z, An H et al (2001) Agrobacterium tumefaciens-mediated transformation of rice with the spider insecticidal gene conferring resistance to leaffolder and striped stem borer. Cell Res 11:149-155. https://doi.org/10.1038/sj.cr.7290080

Huang D, Qiu Y, Zhang Y et al (2013) Fine-mapping and characterization of BPH27, a brown planthopper resistance gene from wild rice (Oryza rufipogon Griff.). Theor Appl Genet 126:219-229

Huang HJ, Liu CW, Xu HJ, Bao YY, Zhang CX (2017) Mucin-like protein, a saliva component involved in brown planthopper virulence and host adaptation. J Insect Physiol 98:223-230

Husnain T, Bokhari SM, Riaz N et al (2003) Pesticidal genes of Bacillus thuringiensis in transgenic rice technology to breed insect resistance. Pak J Biochem Mol Biol 36(3):133-142 
Huvenne H, Smagghe G (2010) Mechanisms of dsRNA uptake in insects and potential of RNAi for pest control: a review. J Insect Physiol 56:227-235

Intikhab S, Karim S, Riazuddin S (2000) Natural variation among rice yellow stem borer and rice leaffolder populations to C delta endotoxins. Pak J Biol Sci 3(8):1285-1289

IRRI (International Rice Research Institute) (1979) Brown planthopper: threat to rice production in Asia. IRRI, Los Baños. 369 p

Jairin J, Phengrat K, Teangdeerith S, Vanavichit A, Toojinda T (2007a) Mapping of a broadspectrum brown planthopper resistance gene, Bph3, on rice chromosome 6. Mol Breed $19: 35-44$

Jairin J, Teangdeerith SN, Leelagud P, Phengrat K, Vanavichit A, Toojinda T (2007b) Physical mapping of Bph3, a brown planthopper resistance locus in rice. Maejo Int J Sci Technol $1: 166-177$

Jairin J, Teangdeerith S, Leelagud P et al (2010) Detection of a brown planthopper resistance gene bph4 at the same chromosomal position of Bph3 using two different genetic backgrounds of rice. Breed Sci 60:71-75

James C (2005) Global status of commercialized biotech/GM crops: 2005. ISAAA brief No. 34. International Service for the Acquisition of Agri-Biotech Applications, Ithaca, NY

Janique S, Sriratanasak W, Ketsuwan K, Jairin J, Jeratthitikul E (2017) Phylogeography of the Asian rice gall midge Orseolia oryzae (Wood Mason) (Diptera: Cecidomyiidae) in Thailand. Genetica 145:37-49

Jena KK, Jeung JU, Lee JH, Choi HC, Brar DS (2006) High-resolution mapping of a new brown planthopper $(\mathrm{BPH})$ resistance gene, $B p h 18(\mathrm{t})$, and marker-assisted selection for $\mathrm{BPH}$ resistance in rice (Oryza sativa L.). Theor Appl Genet 112:288-297

Jiang H, Hu J, Li Z et al (2018) Evaluation and breeding application of six brown planthopper resistance genes in rice maintainer line Jin 23B. Rice 11:22

Jin S, Singh ND, Li L, Zhang X, Daniell H (2015) Engineered chloroplast dsRNA silences cytochrome p450 monooxygenase, V-ATPase and chitin synthase genes in the insect gut and disrupts Helicoverpa armigera larval development and pupation. Plant Biotechnol J 13:435-446

Jing S, Zhang L, Ma Y et al (2014) Genome-wide mapping of virulence in brown planthopper identifies loci that break down host-plant resistance. PLoS One 9:e98911

Jing S, Zhao Y, Du B, Chen R, Zhu L, He G (2017) Genomics of interaction between the brown planthopper and rice. Curr Opin Insect Sci 19:82-87

Kadowaki M, Yoshimura A, Yasui H (2003) RFLP mapping of antibiosis to rice green leafhopper. In: Khush GS, Brar DS, Hardy B (eds) Advances in rice genetics. International Rice Research Institute, Los Baños, pp 270-272

Katiyar SK, Tan Y, Huang B et al (2001) Molecular mapping of gene Gm-6(t) which confers resistance against four biotypes of Asian rice gall midge in China. Theor Appl Genet 103:953-961

Kawaguchi M, Murata K, Ishii T, Takumi S, Mori N, Nakamura C (2001) Assignment of a brown planthopper (Nilaparvata lugens Stål) resistance gene bph4 to the rice chromosome 6. Breed Sci 51(1):13-18

Khajuria C, Vélez AM, Rangasamy M et al (2015) Parental RNA interference of genes involved in embryonic development of the western corn rootworm, Diabrotica virgifera virgifera LeConte. Insect Biochem Mol Biol 63:54-62

Khajuria C, Ivashuta S, Wiggins E et al (2018) Development and characterization of the first dsRNA-resistant insect population from western corn rootworm, Diabrotica virgifera virgifera LeConte. PLoS One 13(5):e0197059. https://doi.org/10.1371/journal.pone.0197059. http:// www.epa.gov/pesticide-registration/registration-rnai-control-corn-rootworm

Khanna HK, Raina SK (2002) Elite indica transgenic rice plants expressing modified CrylAc endotoxin of Bacillus thuringiensis show enhanced resistance to yellow stem borer (Scirpophaga incertulas). Transgenic Res 11:411-423

Kiani G, Nematzadeh G, Ghareyazie B et al (2008) Evaluation of Bt (Bacillus thuringiensis) rice varieties against stem borer (Chilo suppressalis). Pak J Biol Sci 11:648-651. https://doi. org/10.3923/pjbs.2008.648.651 
Kim SM, Sohn JK (2005) Identification of a rice gene (Bphl) conferring resistance to brown planthopper (Nilaparvata lugens Stal) using STS markers. Mol Cell 20:30-34

Kim S, Kim C, Kim WLT et al (2008) Inheritance and field performance of transgenic Korean Bt rice lines resistant to rice yellow stem borer. Euphytica 164:829-839

Kobayashi T, Yamamoto K, Suetsugu Y et al (2014) Genetic mapping of the rice resistance breaking gene of the brown planthopper Nilaparvata lugens. Proc R Soc B 281:20140726

Kola VSR, Renuka P, Madhav MS, Mangrauthia SK (2015) Key enzymes and proteins of crop insects as candidate for RNAi-based gene silencing. Front Physiol 6:119. https://doi. org/10.3389/fphys.2015.00119

Kola VSR, Renuka P, Padmakumari AP et al (2016) Silencing of CYP6 and APN genes affects the growth and development of rice Yellow Stem Borer, Scirpophaga incertulas. Front Physiol 7:20. https://doi.org/10.3389/fphys.2016.00020

Krieg A, Huger AM, Langenbruch GA et al (1983) Bacillus thuringiensis var. tenebrionis: a new pathotype effective against larvae of coleopteran. J Appl Entomol 96:500-508

Kumar S, Arul L, Talwar D (2010) Generation of marker-free Bt transgenic indica rice and evaluation of its yellow stem borer resistance. J Appl Genet 51:243-257. https://doi.org/10.1007/ bf03208854

Kumar K, Sarao PS, Bhatia D et al (2018) High-resolution genetic mapping of a novel brown planthopper resistance locus, Bph34 in Oryza sativa L. X Oryza nivara (Sharma \& Shastry) derived interspecific $\mathrm{F}_{2}$ population. Theor Apppl Genet 131:1163. https://doi.org/10.1007/ s00122-018-3069-7

Lang TN, Buu CB (2003) Genetic and physical maps of gene Bph10 controlling brown planthopper resistance in rice (Oryza sativa L.). Omonrice 11:35-41

Lee M, Aguda R, Cohen M et al (1997) Determination of binding of Bacillus thuringiensis (delta)endotoxin receptors to rice stem borer midguts. Appl Environ Microbiol 63:1453-1459

Leelagud P, Kongsila S, Vejchasarn P et al (2020) Genetic diversity of Asian rice gall midge based on $\mathrm{mtCOI}$ gene sequences and identification of a novel resistance locus gm12 in rice cultivar MN62M. Mol Biol Rep 47:4273. https://doi.org/10.1007/s11033-020-05546-9

Li G, Xu X, Xing H, Zhu H, Fan Q (2005) Insects resistance to Nilaparvata lugens and Cnephalocrosis medinalis in transgenic indica rice and the inheritance of gna+ sbti transgenes. Pest Manag Sci 61:390-396

Li H, Guan R, Guo H, Miao X (2015) New insights into an RNAi approach for plant defence against piercing-sucking and stem-borer insect pests. Plant Cell Environ 38:2277-2285. https://doi.org/10.1111/pce.12546

Ling Y, Weillin Z (2016) Genetic and biochemical mechanisms of rice resistance to planthopper. Plant Cell Rep 35:1559-1572

Liu G, Yan H, Fu Q et al (2001) Mapping of a new gene for brown planthopper resistance in cultivated rice introgressed from Oryza eichingeri. Chin Sci Bull 46:1459-1462

Liu Y, Wu H, Chen H et al (2015) A gene cluster encoding lectin receptor kinases confers broadspectrum and durable insect resistance in rice. Nat Biotechnol 33:301-305

Liu Y, Chen L, Liu Y et al (2016) Marker-assisted pyramiding of two brown planthopper resistance genes, Bph3 and Bph27 (t), into elite rice cultivars. Rice 9:27

Liu Y, Wang Y, Shu C et al (2018) Cry64Ba and Cry64Ca, two ETX/MTX2 Bacillus thuringiensis insecticidal proteins against hemipteran pests. Appl Environ Microbiol 84:e01996-e01917. https://doi.org/10.1128/AEM.01996-17

Mahmood-ur-Rahman RH, Shahid AA, Bashir K, Husnain T, Riazuddin S (2007) Insect resistance and risk assessment studies of advanced generations of basmati rice expressing two genes of Bacillus thuringiensis. Electron J Biotechnol 10(2):15. http://www.ejbiotechnology.info/ content/vol10/issue2/full/3/

Maiti MK, Nayak P, Basu A et al (2001) Performance of $B t$ IR64 rice plants resistant against yellow stem borer in their advanced generations. Food security and environment protection in the new millennium. In: Proceedings Asian Agriculture Congress. IRRI, Los Baños, p 314 
Makkar GS, Bentur JS (2017) Breeding for stem borer and gall midge resistance in rice. In: Arora R, Sandhu S (eds) Breeding insect resistant crops for sustainable agriculture. Springer, Singapore, pp 323-352

Mao YB, Cai WJ, Wang JW et al (2007) Silencing a cotton bollworm P450 monooxygenase gene by plant-mediated RNAi impairs larval tolerance of gossypol. Nat Biotechnol 25:1307-1313

Maqbool SB, Husnain T, Riazuddin S et al (1998) Effective control of yellow stem borer and rice leaf folder in transgenic rice indica varieties Basmati 370 and M7 using the novel endotoxin cryIIA Bacillus thuringiensis gene. Mol Breed 6:1-7

Maqbool SB, Riazuddin S, Loc NT et al (2001) Expression of multiple insecticidal genes confers broad resistance against a range of different rice pests. Mol Breed 7:85-93

Miao YT, Deng Y, Jia HK, Liu YD, Hou ML (2018) Proteomic analysis of watery saliva secreted by white-backed planthopper, Sogatella furcifera. PLoS One 13:e0193831. https://doi. org/10.1371/journal.pone.0193831

Moghaieb R (2010) Transgenic rice plants expressing crylla5 gene are resistant to stem borer (Chilo agamemnon). GM Crops 1:288-293. https://doi.org/10.4161/gmcr.1.5.14276

Murai H, Hashimoto Z, Sharma PN, Shimizu T, Murata K, Takumi S, Mori N, Kawasaki S, Nakamura C (2001) Construction of a high-resolution linkage map of a rice brown planthopper (Nilaparvata lugens Stål) resistance gene bph2. Theor Appl Genet 103(4):526-532

Myint KKM, Fujita D, Matsumura M, Sonoda T, Yoshimura A, Yasui H (2012) Mapping and pyramiding of two major genes for resistance to the brown planthopper (Nilaparvata lugens [Stål]) in the rice cultivar ADR52. Theor Appl Genet 124:495-504

Nagadhara D, Ramesh S, Pasalu IC, Rao YK, Krishnaiah NV, Sarma NP et al (2003) Transgenic indica rice-resistant to sap sucking insects. Plant Biotechnol J 1:231-240

Nagadhara D, Ramesh S, Pasalu IC, Rao YK, Sarma NP, Reddy VD, Rao KV (2004) Transgenic rice plants expressing the snowdrop lectin gene ( $g n a$ ) exhibit high-level resistance to the whitebacked planthopper (Sogatella furcifera). Theor Appl Genet 109:1399-1405

Naik BS, Divya D, Sahu N et al (2018) A new gene Bph33(t) conferring resistance to brown planthopper (BPH), Nilaparvata lugens (Stal) in rice line RP2068-18-3-5. Euphytica 214:53

Nair S, Bentur JS, Sama VSAK (2011) Mapping gall midge resistance genes: towards durable resistance through gene pyramiding. In: Muralidharan K, Siddiq EA (eds) Genomics and crop improvement: relevance and reservations. Institute of Biotechnology, ANGR Agricultural University, Hyderabad, pp 256-264

Nayak P, Basu D, Das S et al (1997) Transgenic elite indica rice plants expressing CryIAcendotoxin of Bacillus thuringiensis are resistant against yellow stem borer (Scirpophaga incertulas). Proc Natl Acad Sci U S A 94:2111-2116

Ojha A, Sinha DK, Padmakumari AP, Bentur JS, Nair S (2017) Bacterial community structure in the Asian rice gall midge reveals a varied microbiome rich in Proteobacteria. Sci Rep 7:9424. https://doi.org/10.1038/s41598-017-09791-0

Painter RH (1951) Insect resistance in crop plants. University of Kansas Press, Lawrence, KS

Pan PL, Ye YX, Lou YH et al (2018) A comprehensive omics analysis and functional survey of cuticular proteins in the brown planthopper. Proc Natl Acad Sci U S A 115:5175. https://doi. org/10.1073/pnas.1716951115

Peng L, Zhao Y, Wang H et al (2017) Functional study of cytochrome P450 enzymes from the brown planthopper (Nilaparvata lugens Stål) to analyze its adaptation to BPH-resistant rice. Front Physiol 8:972

Pradhan S, Chakraborty A, Sikdar N et al (2016) Marker-free transgenic rice expressing the vegetative insecticidal protein (Vip) of Bacillus thuringiensis shows broad insecticidal properties. Planta 244:789-804

Prahalada GD, Shivakumar N, Lohithaswa HC et al (2017) Identification and fine mapping of a new gene, $B P H 31$ conferring resistance to brown planthopper biotype 4 of India to improve rice, Oryza sativa L. Rice 10:41

Price DR, Gatehouse JA (2008) RNAi-mediated crop protection against insects. Trends Biotechnol 26:393-400 
Qiu Y, Guo J, Jing S, Zhu L, He G (2010) High-resolution mapping of the brown planthopper resistance gene Bph6 in rice and characterizing its resistance in the 9311 and Nipponbare near isogenic backgrounds. Theor Appl Genet 121:1601-1611

Qiu Y, Guo J, Jing S, Zhu L, He G (2012) Development and characterization of japonica rice lines carrying the brown planthopper-resistance genes BPH12 and BPH6. Theor Appl Genet 124:485-494

Quilis J, López-García B, Meynard D et al (2014) Inducible expression of a fusion gene encoding two proteinase inhibitors leads to insect and pathogen resistance in transgenic rice. Plant Biotechnol J 12:367-377

Rahman ML, Jiang W, Chu SH, Qiao Y, Ham TH, Woo MO, Lee J, Khanam MS, Chin JH, Jeung JU, Brar DS (2009) High-resolution mapping of two rice brown planthopper resistance genes, Bph20 (t) and Bph21 (t), originating from Oryza minuta. Theor Appl Genet 119(7):1237-1246

Raina SK, Khanna HK, Talwar D et al (2003) Insect bioassays of transgenic indica rice carrying a synthetic $B t$ toxin gene, crylAc. In: Advances in rice genetics, Proceedings of the 4th International Rice Research Conference, pp 567-569

Ramesh S, Nagadhara D, Pasalu IC et al (2004a) Development of stem borer- resistant transgenic parental lines involved in the production of hybrid rice. J Biotechnol 111:131-141

Ramesh S, Nagadhara D, Reddy VD, Rao KV (2004b) Production of transgenic indica rice-resistant to yellow stem borer and sap-sucking insects, using super-binary vectors of Agrobacterium tumefaciens. Plant Sci 166:1077-1085

Ramesh K, Padmavathi G, Dean R, Pandey MK, Lakshmi VJ, Bentur JS (2014) White-backed planthopper Sogatella furcifera (Horvath) (Homoptera: Delphacidae) resistance in rice variety Sinna Sivappu. Euphytica 200:139-148

Rao KV, Rathore KS, Hodges TK et al (1998) Expression of snowdrop lectin (GNA) in transgenic rice plants confers resistance to rice brown planthopper. Plant J 15:469-477

Rawat N, Sinha DK, Rajendrakumar P et al (2010) Role of pathogenesis-related genes in rice-gall midge interactions. Curr Sci 99(10):1361-1368

Rawat N, Neeraja CN, Nair S, Bentur JS (2012a) Differential gene expression in gall midge susceptible rice genotypes revealed by suppressive subtraction hybridization ( $\mathrm{SSH}$ ) cDNA libraries and microarray analysis. Rice 5:8

Rawat N, Neeraja CN, Sundaram RM, Nair S, Bentur JS (2012b) A novel mechanism of gall midge resistance in the rice variety Kavya revealed by microarray analysis. Funct Integr Genom $12: 249-264$

Rawat N, Himabindu K, Neeraja CN, Nair S, Bentur JS (2013) Suppressive subtraction hybridization reveals that rice gall midge attack elicits plant-pathogen like responses in rice. Plant Physiol Biochem 63:122-130

Ren J, Gao F, Wu X et al (2016) Bph32, a novel gene encoding an unknown SCR domaincontaining protein, confers resistance against the brown planthopper in rice. Sci Rep 6:37645

Renganayaki K, Fritz AK, Sadasivam S et al (2002) Mapping and progress toward map-based cloning of brown planthopper biotype-4 resistance gene introgressed from Oryza officinalis into cultivated rice, $O$. sativa. Crop Sci 42:2112-2117

Renuka P, Maganti SM, Padmakumari AP et al (2017) RNA-Seq of rice yellow stem borer, Scirpophaga incertulas reveals molecular insights during four larval developmental stages. G3 (Bethesda) 7:3031. https://doi.org/10.1534/g3.117.043737

Riaz N, Husnain T, Fatima T et al (2006) Development of indica Basmati rice harboring two insecticidal genes for sustainable resistance against lepidopteran insects. South Afr J Bot 72:217-223

Saha P, Majumder P, Dutta I, Ray T, Roy SC, Das S (2006) Transgenic rice expressing Allium sativum leaf lectin with enhanced resistance against sap-sucking insect pests. Planta 223:1329-1343. https://doi.org/10.1007/s00425-005-0182-z

Saka N, Tsuji T, Toyama T, Yano M, Izawa T, Sasaki T (2006) Development of cleaved amplified polymorphic sequence (CAPS) markers linked to a green rice leafhopper resistance gene, Grh3(t). Plant Breed 125:140-143 
Sama VSAK, Himabindu K, Naik BS, Sundaram RM, Viraktamath BC, Bentur JS (2012) Mapping and MAS breeding of an allelic gene to the $G m 8$ for resistance to Asian rice gall midge. Euphytica 187:393-400

Sama VSAK, Rawat N, Sundaram RM et al (2014) A putative candidate for the recessive gall midge resistance gene gm 3 in rice identified and validated. Theor Appl Genet 127:113-124

Sardesai N, Kumar A, Rajyashri KR, Nair S, Mohan M (2002) Identification and mapping of an AFLP marker linked to $G m 7$, a gall midge resistance gene and its conversion to a SCAR marker for its utility in marker aided selection in rice. Theor Appl Genet 105:691-698

Savary S, Willocquet L, Elazegui FA, Castilla NP, Teng PS (2000) Rice pest constraints in tropical Asia: quantification of yield losses due to rice pests in a range of production situations. Plant Dis 84:357-369

Schuler TH, Poppy GM, Kerry BR et al (1998) Insect-resistant transgenic plants. Trends Biotechnol $16: 168-175$

Sengupta S, Chakraborti D, Mondal HA, Das S (2010) Selectable antibiotic resistance marker gene-free transgenic rice harbouring the garlic leaf lectin gene exhibits resistance to sapsucking planthoppers. Plant Cell Rep 29:261-271

Shangguan X, Zhang J, Liu B et al (2018) A mucin-like protein of planthopper is required for feeding and induces immunity response in plants. Plant Physiol 176:552-565

Shao E, Lin L, Chen C et al (2016) Loop replacements with gut-binding peptides in Cry1 Ab domain II enhanced toxicity against the brown planthopper, Nilaparvata lugens (Stål). Sci Rep 6:20106

Shu Q, Ye G, Cui H et al (2000) Transgenic rice plants with a synthetic CrylAb gene from Bacillus thuringiensis were highly resistant to eight lepidopteran rice pest species. Mol Breed 6:433-439

Shu QY, Cui HR, Ye GY et al (2002) Agronomic and morphological characterization of Agrobacterium-transformed Bt rice plants. Euphytica 127:345-352. https://doi.org/10.102 3/a:1020358617257

Sinha DK, Bentur JS, Nair S (2011a) Compatible interaction with its rice host leads to enhanced expression of gamma subunit of oligosaccharyl transferase (OoOST) in the Asian rice gall midge (Orseolia oryzae). Insect Mol Biol 20(5):567-575

Sinha DK, Lakshmi M, Anuradha G et al (2011b) Serine proteases-like genes in the rice gall midge show differential expression in compatible and incompatible interactions with rice. Int J Mol Sci 12:2842-2852

Sinha DK, Atray I, Bentur JS, Nair S (2012a) Expression of nucleoside diphosphate kinase (OoNDPK) is enhanced in rice gall midge feeding on susceptible rice hosts and its overexpression leads to salt tolerance in E. coli. Insect Mol Biol 21(6):593-603

Sinha DK, Nagaraju J, Tomar A, Bentur JS, Nair S (2012b) Pyrosequencing-based transcriptome analysis of the Asian rice gall midge reveals differential response during compatible and incompatible interaction. Int J Mol Sci 13:13079-13103

Sinha D, Atray I, Bentur JS, Nair S (2015) Feeding on resistant rice leads to enhanced expression of defender against apoptotic cell death $(O o D A D 1)$ in the Asian rice gall midge. BMC Plant Biol 15:235

Sinha DK, Atray I, Agarrwal R, Bentur JS, Nair S (2017) Genomics of the Asian rice gall midge and its interactions with rice. Curr Opin Insect Sci 19:76-81

Slamet LIH, Novalina S, Damayanti D et al (2003) Inheritance of crylAb and snowdrop lectin gna genes in transgenic javanica rice progenies and bioassay for resistance to brown planthopper and yellow stem borer. International Rice Research Institute (IRRI), Los Baños, pp 565-566

Srinivasan TS, Almazan MLP, Bernal CC, Ramal AF, Subbarayalu MK, Horgan FG (2016) Interactions between nymphs of Nilaparvata lugens and Sogatella furcifera (Hemiptera: Delphacidae) on resistant and susceptible rice varieties. Appl Entomol Zool 51:81-90

Su C-C, Zhai H-Q, Wang C-MG, Sun LH, Wan J-M (2006) SSR mapping of brown planthopper resistance gene Bph9 in Kaharamana, an indica rice (Oryza sativa L.). Acta Genet Sin 33:262-268 
Suh JP, Yang SJ, Jeung JU et al (2011) Development of elite breeding lines conferring Bph18 genederived resistance to brown planthopper $(\mathrm{BPH})$ by marker-assisted selection and genome-wide background analysis in japonica rice (Oryza sativa L.). Field Crop Res 120:215-222

Sun L, Su C, Wang C, Zhai H, Wan J (2005) Mapping of a major resistance gene to the brown planthopper in the rice cultivar Rathu Heenati. Breed Sci 55:391-396

Sun L-H, Wang C-M, Su C-C, Liu Y-Q, Zhai H-Q, Wan J-M (2006) Mapping and marker-assisted selection of a brown planthopper resistance gene bph2 in rice (Oryza sativa L.). Acta Genet Sin 33:717-723

Sundaram RM (2007) Fine-mapping of rice-gall midge resistance genes $G m 1$ and $G m 2$ and validation of the linked markers. Dissertation. University of Hyderabad, Hyderabad

Sundaram RM, Balachandran SM, Madhav MS, Viraktamath BC (2013) Biotechnological options for rice improvement. In: Shetty PK, Hegde MR, Mahadevappa M (eds) Innovation in rice production. National Institute of Advanced Studies, Bangalore, pp 167-202

Tamura K, Fukuta Y, Hirae M, Oya S, Ashikawa I, Yagi T (1999) Mapping of the Grh1 locus for green rice leafhopper resistance in rice using RFLP markers. Breed Sci 49:11-14

Tamura K, Fukuta Y, Hirae M, Oya S, Ashikawa I, Yagi T (2004) RFLP mapping of a new resistance gene for green rice leafhopper in Kanto PL10. Rice Genet Newsl 21:62-64

Tamura Y, Hattori M, Yoshioka H et al (2014) Map-based cloning and characterization of a brown planthopper resistance gene BPH26 from Oryza sativa L. ssp. indica cultivar ADR52. Sci Rep 4:5872

Tan GX, Wang QM, Ren X, Huang Z, Zhu LL, He GC (2004) Two white-backed planthopper resistance genes in rice share the same loci with those for brown planthopper resistance. Heredity 92:212-217

Tang W, Lin YJ (2007) Field experiment of transgenic crylAb insect resistant rice. Hereditas 29:1008-1012

Terenius O, Papanicolaou A, Garbutt JS et al (2011) RNA interference in Lepidoptera: an overview of successful and unsuccessful studies and implications for experimental design. J Insect Physiol 57:231-245

Thaler JS, Humphrey PT, Whiteman NK (2012) Evolution of jasmonate and salicylate signal crosstalk. Trends Plant Sci 17:260-270

Tomoyasu Y, Denell RE (2004) Larval RNAi in Tribolium (Coleoptera) for analyzing adult development. Dev Genes Evol 214:575-578. https://doi.org/10.1007/s00427-004-0434-0

Tu J, Zhang G, Datta K et al (2000) Field performance of transgenic elite commercial hybrid rice expressing Bacillus thuringiensis delta-endotoxin. Nat Biotechnol 18:1101-1104

Turner CT, Davy MW, MacDiarmid RM, Plummer KM, Birch NP, Newcomb RD (2006) RNA interference in the light brown apple moth, Epiphyas postvittana (Walker) induced by doublestranded RNA feeding. Insect Mol Biol 15:383-391

Venkanna V, Hari Y, Rukminidevi K et al (2018) Marker-assisted selection for pyramiding of gall midge resistance genes in Kavya, a popular rice variety. Int J Curr Microbiol App Sci 7:745-753

Vijayalakshmi P, Amudhan S, Himabindu K, Cheralu C, Bentur JS (2006) A new biotype of the Asian rice gall midge Orseolia oryzae (Diptera: Cecidomyiidae) characterized from the Warangal population in Andhra Pradesh. India Int J Trop Insect Sci 26:207-211

Vila L, Quilis J, Meynard D et al (2005) Expression of the maize proteinase inhibitor (mpi) gene in rice plants enhances resistance against the striped stem borer (Chilo suppressalis): effects on larval growth and insect gut proteinases. Plant Biotechnol J 3:187-202

Wang Y, Wang X, Yuan H et al (2008) Responses of two contrasting genotypes of rice to brown planthopper. Mol Plant-Microbe Interact 21:122-132

Wang Y, Zhang L, Li Y et al (2014) Expression of Cry1Ab protein in a marker-free transgenic $B t$ rice line and its efficacy in controlling a target pest, Chilo suppressalis (Lepidoptera: Crambidae). Environ Entomol 43:528-536

Wang Y, Cao L, Zhang Y et al (2015) Map-based cloning and characterization of BPH29, a B3 domain-containing recessive gene conferring brown planthopper resistance in rice. J Exp Bot 66:6035-6045 
Wang H, Ye S, Mou T (2016a) Molecular breeding of rice restorer lines and hybrids for brown planthopper (BPH) resistance using the Bph14 and Bph15 genes. Rice 9:53

Wang J, Zhang H, Wang $\mathrm{H}$ et al (2016b) Functional validation of cadherin as a receptor of Bt toxin Cry1Ac in Helicoverpa armigera utilizing the CRISPR/Cas9 system. Insect Biochem Mol Biol 76:11-17. https://doi.org/10.1016/j.ibmb.2016.06.008

Wang L, Tang N, Gao X et al (2017a) Genome sequence of a rice pest, the white-backed planthopper (Sogatella furcifera). Giga Sci 6:1-9

Wang Y, Jiang W, Liu H et al (2017b) Marker-assisted pyramiding of Bph6 and Bph9 into elite restorer line 93-11 and development of functional marker for Bph9. Rice 10:51

Wang W, Wan P, Lai F, Zhu T, Fu Q (2018) Double-stranded RNA targeting calmodulin reveals a potential target for pest management of Nilaparvata lugens. Pest Manag Sci 74:1711-1719. https://doi.org/10.1002/ps.4865

Waris MI, Younas A, ul Qamar MT et al (2018) Silencing of chemosensory protein gene NlugCSP8 by RNAi induces declining behavioral responses of Nilaparvata lugens. Front Physiol 9:379. https://doi.org/10.3389/fphys.2018.00379

Wu C, Fan Y, Zhang C et al (1997a) Transgenic fertile japonica rice plants expressing a modified $c r y 1 A b$ gene resistant to yellow stem borer. Plant Cell Rep 17:129-132

Wu C, Zhao R, Fan Y et al (1997b) Transgenic rice plants resistant to yellow stem borer. Rice Biotechnol 9:7

Wu J, Maehara T, Shimokawa T et al (2002) A comprehensive rice-transcript map containing 6591 expressed sequence tag sites. Plant Cell Online 14:525-535

Wu H, Liu Y, He J et al (2014) Fine-mapping of brown planthopper (Nilaparvata lugens Stål) resistance gene Bph28 (t) in rice (Oryza sativa L.). Mol Breed 33:909-918

Wunn J, Kloti A, Burkhardt P et al (1996) Transgenic indica rice breeding line IR58 expressing a synthetic crylA $(b)$ gene from Bacillus thuringiensis provides effective insect pest control. Nat Biotechnol 14:171-176

Xue J, Zhou X, Zhang CX et al (2014) Genomes of the rice pest brown planthopper and its endosymbionts reveal complex complementary contributions for host adaptation. Genome Biol 15:521

Xue WH, Xu N, Yuan XB et al (2018) CRISPR/Cas9-mediated knockout of two eye pigmentation genes in the brown planthopper, Nilaparvata lugens (Hemiptera: Delphacidae). Insect Biochem Mol Biol 93:19-26

Yamasaki M, Yoshimura A, Yasui H (2003) Genetic basis of ovicidal response to white-backed planthopper (Sogatella furcifera Horvath) in rice (Oryza sativa L.). Mol Breed 12:133-143

Yang H, You A, Yang Z et al (2004) High-resolution genetic mapping at the Bph15 locus for brown planthopper resistance in rice (Oryza sativa L.). Theor Appl Genet 110:182-191

Yang Z, Chen H, Tang W et al (2011) Development and characterization of transgenic rice expressing two Bacillus thuringiensis genes. Pest Manag Sci 67:414-422

Yang L, Li RB, Li YR et al (2012) Genetic mapping of bph20 (t) and bph21(t) loci conferring brown planthopper resistance to Nilaparvata lugens Stål in rice (Oryza sativa L.). Euphytica 183:161-171

Yang Y, Mei F, Zhang W et al (2014) Creation of Bt rice expressing a fusion protein of $c r y 1 A c$ and CrylI-like using a green tissue-specific promoter. J Econ Entomol 107:1674-1679

Yarasi B, Sadumpati V, Pasalu IC, Reddy DV, Rao KV (2008) Transgenic rice expressing Allium sativum leaf agglutinin (ASAL) exhibits high-level resistance against major sap-sucking pests. BMC Plant Biol 8:102. https://doi.org/10.1186/1471-2229-8-102

Ye G, Shu Q, Cui H et al (2000) A leaf-section bioassay for evaluating rice stem borer resistance in transgenic rice containing a synthetic cry $1 A b$ gene from Bacillus thuringiensis Berliner. Bull Entomol Res 90:179-182. https://doi.org/10.1017/s0007485300000298

Ye G, Shu Q, Yao H et al (2001) Field evaluation of resistance of transgenic rice containing a synthetic crylAb gene from Bacillus thuringiensis Berliner to two stem borers. J Econ Entomol 94:271-276 
Ye R, Huang H, Yang Z et al (2009) Development of insect-resistant transgenic rice with CrylCfree endosperm. Pest Manag Sci 65:1015-1020

Ye W, Yu H, Jian Y et al (2017a) A salivary EF-hand calcium-binding protein of the brown planthopper Nilaparvata lugens functions as an effector for defense responses in rice. Sci Rep 7:40498

Ye ZF, Liu XL, Han Q et al (2017b) Functional characterization of PBP1 gene in Helicoverpa armigera (Lepidoptera: Noctuidae) by using the CRISPR/Cas9 system. Sci Rep 7:8470. https:// doi.org/10.1038/s41598-017-08769-2

Yin K, Gao C, Qiu JL (2017) Progress and prospects in plant genome editing. Nat Plants 3:17107

Yoshimura S, Komatsu M, Kaku K et al (2012) Production of transgenic rice plants expressing Dioscorea batatas tuber lectin1 to confer resistance against brown planthopper. Plant Biotechnol 29:501-504

Yu R, Xu X, Liang Y et al (2014) The insect ecdysone receptor is a good potential target for RNAibased pest control. Int J Biol Sci 10:1171-1180. https://doi.org/10.7150/ijbs.9598

Zamore PD, Tuschl T, Shorp PA, Bartel DP (2000) RNAi: double-stranded RNA directs the ATPdependent cleavage of mRNA at 21 to 23 nucleotide intervals. Cell 101:25-33

Zeng Q, Wu Q, Zhou K et al (2002) Obtaining stem borer-resistant homozygous transgenic lines of Minghui 81 harboring novel crylAc gene via particle bombardment. Yi Chuan Xue Bao 29:519-524

Zeng F, Liu H, Zhang A et al (2018) Three chemosensory proteins from the rice leaffolder Cnaphalocrocis medinalis involved in host volatile and sex pheromone reception. Insect Mol Biol 27:710. https://doi.org/10.1111/imb.12503

Zha W, Peng X, Chen R, Du B, Zhu L, He G (2011) Knockdown of midgut genes by dsRNAtransgenic plant-mediated RNA interference in the Hemipteran insect Nilaparvata lugens. PLoS One 6:e20504

Zhang Y, Li Y, Zhang Y et al (2011) Seasonal expression of Bt proteins in transgenic rice lines and the resistance against Asiatic rice borer Chilo suppressalis (Walker). Environ Entomol 40:1323-1330

Zhang KJ, Zhu WC, Rong X et al (2013) The complete mitochondrial genomes of two rice planthoppers, Nilaparvata lugens and Laodelphax striatellus: conserved genome rearrangement in Delphacidae and discovery of new characteristics of atp8 and tRNA genes. BMC Genomics 14:417

Zhang KJ, Zhu WC, Rong X et al (2014) The complete mitochondrial genome sequence of Sogatella furcifera (Horváth) and a comparative mitogenomic analysis of three predominant rice planthoppers. Gene 533:100-109

Zhang J, Khan SA, Hasse C, Ruf S, Heckel DG, Bock R (2015) Full crop protection from an insect pest by expression of long double-stranded RNAs in plastids. Science 347:991-994

Zhang L, Qiu LY, Yang HL et al (2017) Study on the effect of wing bud chitin metabolism and its developmental network genes in the brown planthopper, Nilaparvata lugens, by knockdown of TRE gene. Front Physiol 8:750

Zhao Q (2015) Generation of insect-resistant and glyphosate-tolerant rice by introduction of a T-DNA containing two Bt insecticidal genes and an EPSPS gene. J Zhejiang Univ Sci B 16(10):824-831

Zhao L, Yang M, Shen Q et al (2016a) Functional characterization of three trehalase genes regulating the chitin metabolism pathway in rice brown planthopper using RNA interference. Sci Rep 6:27841. https://doi.org/10.1038/srep27841

Zhao Y, Huanga J, Wanga Z et al (2016b) Allelic diversity in an NLR gene BPH9 enables rice to combat planthopper variation. Proc Natl Acad Sci U S A 113:45

Zhou WW, Liang QM, Xu Y et al (2013) Genomic insights into the Glutathione S-transferase gene family of two rice planthoppers, Nilaparvata lugens (Stål) and Sogatella furcifera (Horváth) (Hemiptera: Delphacidae). PLoS One 8(2):e56604. https://doi.org/10.1371/journal. pone.0056604 
Zhu GH, Peng YC, Zheng MY et al (2017a) CRISPR/Cas9-mediated BLOS2 knockout resulting in disappearance of yellow strips and white spots on the larval integument in Spodoptera litura. J Insect Physiol 103:29-35

Zhu J, Hao P, Lu C, Ma Y, Feng Y, Yu X (2017b) Expression and RNA interference of ribosomal protein L5 gene in Nilaparvata lugens (Hemiptera: Delphacidae). J Insect Sci 17:73. https:// doi.org/10.1093/jisesa/iex047

Zhu J, Jiang F, Wang X et al (2017c) Genome sequence of the small brown planthopper, Laodelphax striatellus. Giga Sci 6:1-12

Zimmer CT, Garrood WT, Singh SK et al (2018) Neofunctionalization of duplicated P450 genes drives the evolution of insecticide resistance in the brown planthopper. Curr Biol 28:268-274

Zuo Y, Wang H, Xu Y et al (2017) CRISPR/Cas9-mediated G4946E substitution in the ryanodine receptor of Spodoptera exigua confers high levels of resistance to diamide insecticides. Insect Biochem Mol Biol 89:79-85

Open Access This chapter is licensed under the terms of the Creative Commons Attribution 4.0 International License (http://creativecommons.org/licenses/by/4.0/), which permits use, sharing, adaptation, distribution and reproduction in any medium or format, as long as you give appropriate credit to the original author(s) and the source, provide a link to the Creative Commons license and indicate if changes were made.

The images or other third party material in this chapter are included in the chapter's Creative Commons license, unless indicated otherwise in a credit line to the material. If material is not included in the chapter's Creative Commons license and your intended use is not permitted by statutory regulation or exceeds the permitted use, you will need to obtain permission directly from the copyright holder.

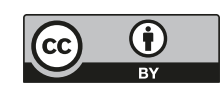

